\title{
Bir Koster için Yardımcı Güç Kaynağı Olarak Katı Oksit Yakıt Pilinin Termodinamik, Ekonomik ve Çevresel Analizi
}

\author{
Engin Güler ${ }^{1,2}$, Selma Ergin ${ }^{2}$, Barış Barlas ${ }^{3}$ \\ ${ }^{1}$ Piri Reis Üniversitesi, Mühendislik Fakültesi, Tuzla, İstanbul, Türkiye \\ 2,3 İstanbul Teknik Üniversitesi, Gemi İnşaatı ve Deniz Bilimleri Fakültesi, Maslak, İstanbul, Türkiye \\ 1 eguler@pirireis.edu.tr, ORCID: 0000-0002-1553-4553 \\ 2 (sorumlu yazar), ergin@itu.edu.tr, 0000-0001-8343-2455 \\ 3 barlas@itu.edu.tr, 0000-0002-5846-2369
}

\section{ÖZET}

Çevre ve dünya iklimleri açısından karbondioksit $\left(\mathrm{CO}_{2}\right)$ emisyonlarının azaltılması oldukça önemli olup Uluslararası Denizcilik Örgütü (IMO) de son yıllarda uluslararası denizcilik faaliyetlerinden kaynaklanan sera gazı emisyonlarının sınırlandıııması yönünde çalışmalarını hızlandırmıştır. Gemilerden salınan $\mathrm{CO}_{2}$ emisyonlarının azaltılması için bugüne kadar çok çeşitli yöntemler ve teknolojiler önerilmiştir. Bu teknolojilerden birisi olan yakıt pilleri kullanılan yakıta bağlı olarak $\mathrm{CO}_{2}$ emisyonlarını sıfıra kadar düşürebilmektedir. Bu çalışmada bir koster için yardımcı güç kaynağı olarak katı oksit yakıt pili (SOFC) kullanımının elektrokimyasal ve termodinamik olarak modellenmesi ve Aspen HYSYS yazılımında simülasyonu gerçekleştirilmiştir. Alternatif $\mathrm{CO}_{2}$ emisyon azaltma yöntemleri ile fizibilite ve maliyet açısından daha etkin bir karşılaştırma yapabilmek için birim $\mathrm{CO}_{2}$ azaltma maliyeti üzerinden sistemin ekonomik analizi gerçekleştirilmiştir. Ekonomik analiz, çalışmada kullanılan geminin referans yardımcı güç sisteminin bu çalışmada önerilen SOFC güç sistemi ile değiştirilmesinden kaynaklanan maliyet artışı ve azaltılan $\mathrm{CO}_{2}$ emisyon miktarı değerlerinden yola çıkılarak yapılmıştır. Kurulan model üzerinden yakıt pilinin farklı çalışma sıcaklıkları ve akım yoğunluklarının sistemin maliyeti üzerine etkileri incelenmiştir. Ayrıca gemiler için yapılan çalışmalarda ilk defa yakıt pili kimyasal bozulmasının pil potansiyeli düşüşündeki etkisi bu çalışmada dikkate alınmıştır. Yapılan parametrik çalışma sonucunda incelenen koşullarda akım yoğunluğunun seçimi birim $\mathrm{CO}_{2}$ azaltma maliyetini \%10.0'a, sıcaklığın seçimi ise birim $\mathrm{CO}_{2}$ azaltma maliyetini \%26.1'e kadar azaltmıştır. Maliyeti minimize eden çalışma koşullarında sistemin kimyasal bozulma öncesi \%51.1 gibi yüksek bir termal verime ve $302.2 \mathrm{USD} /$ ton $\mathrm{CO}_{2}$ azaltma maliyetine sahip olduğu hesaplanmıştır. Belirlenen koşulda SOFC güç sisteminin toplam maliyetinin \%65'ini kullanılan yakıt olan hidrojenin oluşturduğu görülmüştür. Kimyasal bozulma etkisiyle verim yakıt pili ömrü sonunda ortalama \%43.6 olarak elde edilmiş olup bu verim referans yardımcı güç sisteminden \%20.7 daha fazladır. Referans koşullardaki gemiye göre $\mathrm{CO}_{2}$ emisyonları çalışmada önerilen yardımcı güç sistemi ile \%24.3 kadar azalmıştır.

Anahtar kelimeler: Katı oksit yakıt pili, gemi yardımcı güç sistemleri, temiz enerji, gemi emisyonları, $\mathrm{CO}_{2}$ emisyonları

Makale geçmişi: Geliş 05/08/2021 - Kabul 02/12/2021

https://doi.org/10.54926/gdt.979252 


\title{
Thermodynamic, Economic and Environmental Analysis of a Solid Oxide Fuel Cell as Auxiliary Power Source for a Coaster
}

\author{
Engin Güler ${ }^{1,2}$, Selma Ergin ${ }^{2}$, Barış Barlas ${ }^{3}$ \\ ${ }^{1}$ Piri Reis University, Faculty of Engineering, Tuzla, Istanbul, Turkey \\ ${ }^{2,3}$ Istanbul Technical University, Faculty of Naval Architecture and Ocean Engineering, Maslak, Istanbul, Turkey \\ 1 eguler@pirireis.edu.tr, ORCID: 0000-0002-1553-4553 \\ ${ }^{2}$ (corresponding author), ergin@itu.edu.tr, 0000-0001-8343-2455 \\ 3 barlas@itu.edu.tr, 0000-0002-5846-2369
}

\begin{abstract}
Reducing carbon dioxide $\left(\mathrm{CO}_{2}\right)$ emissions is crucial in terms of environment and world climates, and the International Maritime Organization (IMO) has accelerated its works to limit greenhouse gas emissions released from international maritime activities in recent years. Various methods and technologies have been proposed to reduce $\mathrm{CO}_{2}$ emissions from ships until nowadays. Fuel cells are one of these technologies and they can reduce $\mathrm{CO}_{2}$ emissions to zero, depending on the fuel used. In this study, electrochemical and thermodynamic modeling of the solid oxide fuel cell (SOFC) as an auxiliary power source for a coaster and simulation in Aspen HYSYS software is carried out. In order to make a more effective comparison in terms of feasibility and cost with alternative $\mathrm{CO}_{2}$ emission reduction methods, an economic analysis of the system is made over unit $\mathrm{CO}_{2}$ reduction cost. The economic analysis is carried out based on the cost increase and reduced $\mathrm{CO}_{2}$ emission values resulting from the replacement of the reference auxiliary power system of the ship used with the SOFC power system proposed in this study. The effects of different operating temperatures and current densities of the fuel cell on the cost of the system are investigated using the model established. In addition, the effect of fuel cell degradation on cell potential reduction is taken into account in this study for the first time in studies conducted for ships. As a result of the parametric study, the selection of the current density in the conditions examined reduces the unit $\mathrm{CO}_{2}$ reduction cost up to $10.0 \%$ and the selection of the temperature reduces the unit $\mathrm{CO}_{2}$ reduction cost up to $26.1 \%$. It has been calculated that the system has high thermal efficiency of $51.1 \%$ and a reduction cost of 302.2 USD/ton $\mathrm{CO}_{2}$ under operating conditions that minimize costs. It has been calculated that $65 \%$ of the total cost of the SOFC power system under the specified condition is hydrogen as the fuel used. The efficiency with the degradation effect is calculated as $43.6 \%$ on average at the end of the fuel cell life, and this efficiency is $20.7 \%$ greater than the reference auxiliary power system. Compared to the ship in the reference conditions, $\mathrm{CO}_{2}$ emissions decreased by $24.3 \%$ with the auxiliary power system proposed in the study.
\end{abstract}

Keywords: Solid oxide fuel cell, ship auxiliary power systems, clean energy, ship emissions, $\mathrm{CO}_{2}$ emissions

Article history: Received 05/08/2021 - Accepted 02/12/2021 


\section{Sembol ve Kısaltma Listesi}

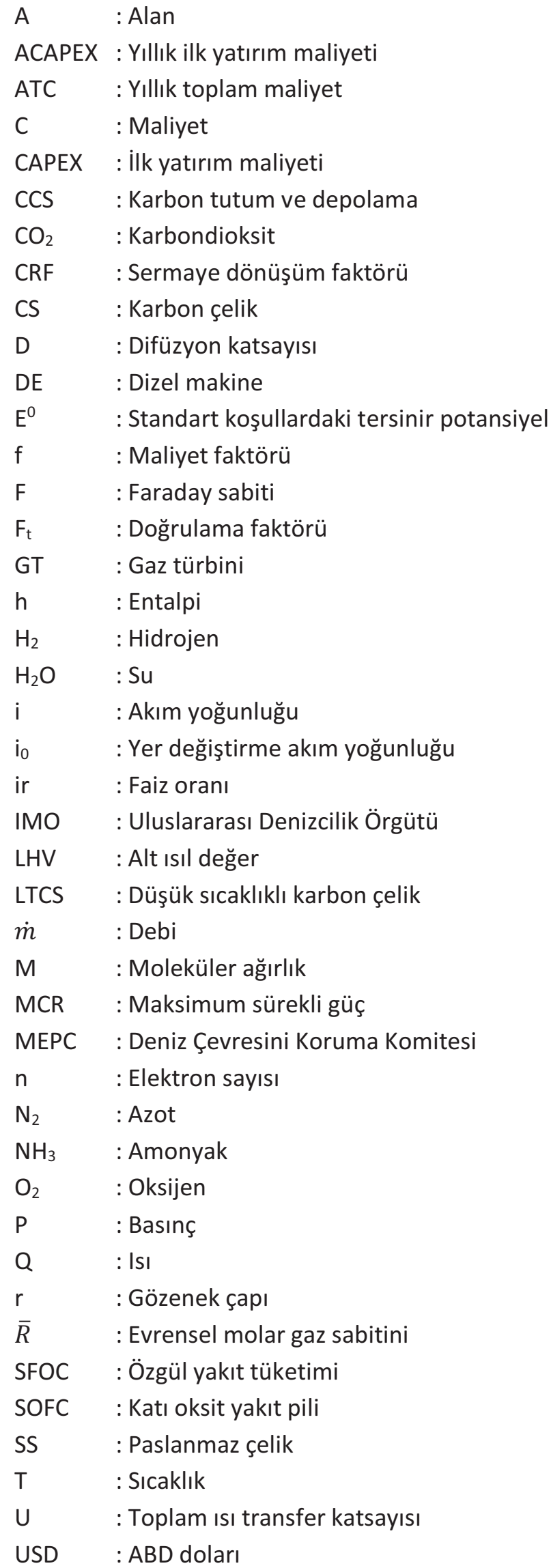




\section{Giriş}

Uluslararası Denizcilik Örgütü (IMO), 2008 yııından bu yana çalışmalarını önemli ölçüde hızlandırmış ve uluslararası deniz taşımacılığından kaynaklanan karbondioksit $\left(\mathrm{CO}_{2}\right)$ emisyonlarını sınırlandırmak için çeşitli fazlar halinde bir dizi kural ve düzenlemeleri yürürlüğe koymuştur. 2018 yılında yapılan 72. Deniz Çevresini Koruma Komitesi (MEPC) toplantısı sonucunda, 2050 yılına kadar $\mathrm{CO}_{2}$ emisyonlarının 2008 yılına göre \%50 azaltılacağı kabul edilmiştir (International Maritime Organization, 2018). 2019 ve 2020 yıllarında yapılan 74. ve 75. MEPC toplantıları sonucunda ise $\mathrm{CO}_{2}$ emisyonlarının farklı gemi tipleri için çeşitli oranlarda \%50'ye kadar azaltılması ve gemilerin yaydıkları $\mathrm{CO}_{2}$ oranına göre sınıflandırılması kabul edilmiştir. Ayrıca, geçmişte $\mathrm{CO}_{2}$ emisyon azaltımı için kabul edilen fazların uygulama tarihleri daha da öne alınmıştır (Marine Environment Protection Committee, 2020).

$\mathrm{CO}_{2}$ emisyonlarını azaltmak için alınan kararlar, çevre ve dünya iklimleri açısından olumlu gelişmelerdir. Ancak karbon vergisi ve $\mathrm{CO}_{2}$ emisyonlarını sınırlamak için kullanılacak yeni teknolojilerin getirdiği ekonomik yükümlülükler nedeniyle denizcilik sektörü ve dünya ticareti açısından olumsuz sonuçları vardır. $\mathrm{CO}_{2}$ emisyonlarını azaltmak için bugüne kadar oldukça çeşitli teknolojiler ve yöntemler önerilmiş olup bu yöntemlerden yakıt olarak biyoyakıt, amonyak $\left(\mathrm{NH}_{3}\right)$ veya hidrojen $\left(\mathrm{H}_{2}\right)$ kullanımı, tahrik sistemlerinde yakıt pilleri, yenilenebilir enerji kaynakları, batarya ve elektrik kullanımı gibi yöntemler ne yazık ki yeterince ekonomik çözümler sunamamaktadırlar (Lloyd's Register, 2018). Karbon tutma ve depolama sistemi yüksek güverte alanına ve güç ihtiyacına sahip büyük gemiler için uygun bir çözüm olabilmekle birlikte küçük gemilerde kullanımı yeterince uygun olmayabilir (Güler ve Ergin, 2021). Gövde ve form tasarımını geliştirmek, güç ve sevk sistemlerini iyileştirmek ve bunun gibi enerji verimini artıran diğer yöntemlerin ise $\mathrm{CO}_{2}$ emisyonlarını azaltma üzerinde etkileri sınırlıdır (Buhaug vd., 2009).

Yüksek maliyetlerine rağmen geleneksel içten yanmalı gemi makineleri ile karşılaştırıldığında yakıt pilleri daha verimli, daha temiz ve daha sessizdir. Bu nedenlerle yakıt pili kullanımı iklim değişikliği ile mücadelede umut vericidir ve son yıllarda dünya çapında ilgi görmeye başlamıştır (Bassam vd., 2017). Yakıt pillerinin gemilerde kullanımı ile ilgili ilk uygulamalar denizaltılar için gerçekleştirilmiş olup, 2000'li yıllardan itibaren araştırmacılar, yakıt pillerinin ticari gemilerde özellikle yardımcı sistemler olmak üzere güç sistemlerinde kullanımını incelemeye başlamışlardır (Armi vd., 2021; Choi vd., 2016; Evrin ve Dincer, 2019). Bugüne kadar gemilerde çeşitli tipte yakıt pilleri kullanımı uygulanmak ve önerilmekle birlikte pillerin performansları karşılaştııılığında yüksek atık ısı değerlendirme potansiyeli ve yüksek verimleri dolayısıyla katı oksit yakıt pillerinin (SOFC) gemiler için daha iyi bir seçenek olacağı öngörülmüştür (Yan vd., 2019; Zhang vd., 2010). Bu bağlamda yapılan bir çalışmada, en yaygın kullanımı olan proton değişim membranlı yakıt pili tipinin hidrojen depolama yoğunluğunun düşük olması sebebiyle seyir süresinin 100 saatin biraz üzerinde olduğu ve bir güç üretim ekipmanı olarak uzun deniz yolculuklarını desteklemediği, bunun yerine SOFC güç sistemlerinin yakıt depolama yoğunluğunun 1.5-5 kat fazla olması sebebiyle çok daha uzun seyir süresi imkanı sağladığı ve emisyonları etkili bir şekilde azaltarak görev gereksinimlerini tatmin edici bir düzeyde gerçekleştirdiği gösterilmiştir (van Biert vd., 2016). Ayrıca SOFC güç sistemi, alt ısıl ve hibrit güç çevrimleri ile birlikte daha yüksek verimlere ulaşabilmektedir (Park vd., 2000). Büyük bir etan taşıyıcı geminin alternatif hibrit güç sistemleri için performansının belirlendiği bir çalışmada çift yakıtlı dizel elektrik makine ile alt Isıl çevriminde gaz türbini (GT) kullanan bir SOFC hibrit sisteminin IMO'nun istenilen emisyon azaltım gereksinimini karşılayan uygun bir çözüm olduğu tespit edilmiştir (Ahn vd., 2018). Gemiler için SOFC-GT güç çevrimi ile süperkritik $\mathrm{CO}_{2}$, organik Rankine, $\mathrm{NH}_{3}$-su absorpsiyon soğutması ve yüksek basınçlı ters osmoz su arıtma tesisi alt çevrimlerinin kullanıldığı bir kombine ısı ve güç sisteminin toplam veriminin \%67'ye kadar çıkabileceği gösterilmiştir (Ouyang vd., 2020). Aframax tipi bir ham petrol tankeri için yapılan bir çalışmada ise SOFC ile gaz yakıtlı içten yanmalı makinelerin kullanıldığı hibrit bir 
sistem ile, hibrit sistemin entegrasyon düzeyinin $\mathrm{CO}_{2}$ emisyonları ve ekserjik verime etkisi incelenmiştir (Giap vd., 2020). Bir tanker ve cruise gemisinin incelendiği başka bir çalışmada ise dizel ve gaz yakıtı makineler ile SOFC toplam güç üretimine çeşitli miktarlarda katkılarının sera gazı emisyonları ve güç üretim sistemi maliyetleri üzerine olan etkisi incelenmiştir (Baldi vd., 2020). Gemilerde gaz enjeksiyonlu makine ile SOFC kullanılan bir güç çevrimi ile ilgili başka bir çalışmada ise yakıt pilinden çıkan anot ve katot egzoz gazlarının bir kazanda yakılarak kullanılması yerine atık ısı sistemine ayrı ayrı entegrasyonu ve anottaki yanmamış hidrokarbonların içten yanmalı makinede doğal gaz ile karıştırılarak birlikte enjeksiyonu önerilmiş ve önerilen sistemin emisyonlar üzerine etkileri incelenmiştir (Sapra vd., 2021).

Bu çalışmada yardımcı güç kaynağı olarak SOFC güç sisteminin bir koster için yakıt pilinin elektrokimyasal olarak, güç çevriminin ise Aspen HYSYS yazılımında termodinamik olarak modellenmesi ve simülasyonu gerçekleştirilmiştir (Aspentech Inc, 2015). Kurulan modelin ekonomik analizi yapılmış, yakıt pili çalışma sıcaklığı ve akım yoğunluğunun sistemin maliyeti ve ekserji verimi üzerine etkileri incelenmiştir. Ekonomik analiz sonuçlarına göre en uygun yakıt pili çalışma sıcaklığı ve akım yoğunluğu parametreleri belirlenmiş ve en uygun çalışma sıcaklığı koşulu için yakıt pilindeki kayıpların, akım yoğunluğu değişimine bağıı olarak etkisi incelenmiştir.

Bu çalışmada önceki çalışmalardan farklı olarak ekonomik analiz, sistemin toplam maliyeti ve sisteme sağlanan birim güç başına maliyet yerine atmosfere salınan birim $\mathrm{CO}_{2}$ miktarı azaltma maliyeti üzerinden gerçekleştirilmiştir. Böylece elde edilen sonuçların diğer $\mathrm{CO}_{2}$ emisyonu azaltma yöntemleri ile karşılaştırılması açısından daha gerçekçi bir yaklaşım yapılmıştır. Yine bu çalışmada, gemilerde yakıt pili kullanımı ile ilgili yapılan diğer çalışmalardan farkı olarak yakıt pili kimyasal bozulmanın voltaj düşüşündeki etkisi de dikkate alınmıştır. Ayrıca yazarların literatür taraması sırasında incelediği makalelerde gemilerde yakıt pili kullanımı ile ilgili akım yoğunluğu ve sıcaklığın sistemin maliyeti üzerindeki etkisinin incelenmediği görülmüştür. Bu incelemenin sonucunda çalışma akım yoğunluğunun seçiminin birim $\mathrm{CO}_{2}$ azaltma maliyetini \%10.0'a, sıcaklığın seçiminin ise birim $\mathrm{CO}_{2}$ azaltma maliyetini \%26.08'e kadar azalttığı hesaplanmıştır. SOFC güç sisteminin $\mathrm{CO}_{2}$ azaltma maliyeti ise 302.2 usd/ton $\mathrm{CO}_{2}$ olarak hesaplanmış olup literatürdeki gemilerde kullanılan yakıt pillerine göre çok daha uygun maliyetli olduğu görülmüştür. (Lloyd's Register, 2018).

\section{Referans Gemi Seçimi}

Günümüzde yakıt pillerinin güç kaynağı olarak kullanıldığı güç üretim tesislerinde $50 \mathrm{MW}$ 'ı aşan güç elde etmek mümkündür (Zhang vd., 2010). Gemiler ile ilgili yapılan çalışmalarda bugüne kadar test edilen en büyük kapasiteli yakıt pilinin gücü ise 2.5 MW'tır (Dall'Armi vd., 2021). Bu yakıt pilinin ise sadece yakıt dönüşüm ünitesi gemide test edilmiş olup yakıt pili karada test edilmiştir. Şu an Norveçte sürdürülen ve gelecekte tamamlanması beklenen ShipFC projesinde bir offshore destek gemisi için 2 MW güç üretim kapasitesine sahip bir SOFC olmak üzere 3.2 MW'a kadar çeşitli güç kapasitelerine sahip yakıt pillerinin gemilerde kullanımı gerçekleşecektir (Dall'Armi vd., 2021; De-Troya vd., 2016). Bu gelişmeler göz önüne alınarak seçilen geminin servis hızındaki yardımcı güç ihtiyacının burada verilen güç değerlerinin çok üstünde olmaması başta ekonomik analiz olmak üzere sonuçların doğruluğu açısından önemlidir. Diğer taraftan Avrupa Birliği Parlamentosu, 1 Ocak 2022'den itibaren uygulanmaya başlayacak şekilde 5.000 grostondan büyük gemilerin de kara tesislerinde olduğu gibi karbon vergisi ödemesi kararını almıştır (Marine Insight, 2020). Bu gelişme ise Avrupa Birliği karasularında çalışan ve 5.000 grostondan büyük gemiler için yakıt pili kullanımının diğer gemilere kıyasla daha uygun olabileceğini göstermektedir. Bütün bu veriler göz önüne alınarak seçilen referans geminin özellikleri Tablo 1'de verilmiştir (Bureau Veritas, 2021). 
Tablo 1'de verilen referans geminin dizel ana makinesinin modeli 8DKM-28 olup özgül yakıt tüketimi \%75 Maksimum sürekli güçte (MCR) $185 \mathrm{~g} / \mathrm{kWh}$ olarak tespit edilmiştir (Woodyard, 2009). Dizel jeneratörlerin özgül yakıt tüketimi ise ortalama $206 \mathrm{~g} / \mathrm{kWh}$ olarak kabul edilmiştir (MTU-solutions, 2019).

Tablo 1. Referans gemi özellikleri

\begin{tabular}{lcc}
\hline Özellikler & Değer & Birim \\
\hline Gemi adı & Breadbox Warthog & \\
Tip & Koster & \\
Dikmeler arası boy & 116.2 & $\mathrm{~m}$ \\
Genişlik & 18 & $\mathrm{~m}$ \\
Su çekimi & 7 & $\mathrm{~m}$ \\
Servis hızı & 15 & $\mathrm{kn}$ \\
Gros tonaj & 6494 & \\
Ana makine güç ihtiyacı & 2500 & $\mathrm{~kW}$ \\
Ana makine SFOC & 185 & $\mathrm{~g} / \mathrm{kWh}$ \\
Dizel jeneratör güç ihtiyacı & $250 \times 3$ & $\mathrm{~kW}$ \\
Dizel jeneratör SFOC & 206 & $\mathrm{~g} / \mathrm{kWh}$ \\
\hline
\end{tabular}

\section{Sistemin Modellenmesi}

\subsection{SOFC'nin elektrokimyasal olarak modellenmesi}

Bu çalışmada $\mathrm{CO}_{2}$ emisyonlarını en etkili düzeyde azaltmak ve yüksek maliyetine rağmen azaltılan birim $\mathrm{CO}_{2}$ başına maliyeti düşürmek açısından yakıt olarak saf $\mathrm{H}_{2}$ kullanılmıştır. Bu durumda SOFC'nin elektrokimyasal modelinde kullanılan tüm denklemler Tablo 2'de gösterilmiştir.

Denklem (1), (2), (3) sırasıyla anot ve katot tarafları ile toplam reaksiyonları göstermektedir. Yakıt pilinin net potansiyeli $\left(V_{\text {cell }}\right)$ ise denklem (4) ile tespit edilmiştir. Burada $V_{\text {Nernst }}, V_{\text {act }}, V_{\text {ohm }}, V_{\text {con }}$ sırasıyla Nernst potansiyelini, etkinleşme (aktivasyon) kayıplarını, direnç kayıplarını ve konsantrasyon kayıplarını temsil etmektedir. Nernst potansiyeli elektrokimyasal reaksiyonlar aracılığı ile elde edilebilecek teorik maksimum potansiyeldir.

Denklem (5)'te $E^{0}$ standart koşullardaki tersinir potansiyeli, $\bar{R}$ evrensel molar gaz sabitini $\left(J . \mathrm{mol}^{-1} \cdot \mathrm{K}^{-1}\right)$, $n \mathrm{H}_{2}$ 'nin elektron sayısını, $F$ Faraday sabitini, $P$ kısmi basıncı, an indisi anot tarafını, cat indisi katot tarafını ve $T$ sıcaklığı (K) temsil etmektedir. $E^{0}$, Gibbs serbest enerjisi $(\Delta \bar{g})$ ile tanımlanmakta olup denklem (6)'ya göre ifade edilir. Gibbs serbest enerjisi ise denklem (7)'de olduğu gibi sıcaklığın bir fonksiyonu olarak ifade edilebilir.

Nernst potansiyelini hesaplayabilmek için malzemelerin baca gazı çıkışındaki mol dağılımlarının bilinmesi gerekmektedir. Bunu belirleyebilmek için de yakıt ve havanın kullanım faktörlerinin bilinmesi gerekir. Yakıt için kullanım faktörü 0.85 hava içinse 0.50 seçilmiştir (Ahn vd., 2018; Ouyang vd., 2020). Ayrıca havanın \%20.79 $\mathrm{O}_{2}$, \%78.21 $\mathrm{N}_{2}$ ve \%1 oranında su buharından oluştuğu kabul edilmiştir.

Etkinleşme kayıplarını hesaplamak için Tafel denklemi (8) kullanılır. Burada $i$ seçilen akım yoğunluğu ve $i_{0}$ yer değiştirme akım yoğunluğu olup SOFC'nin katot ve anot için deneysel sonuçlardan elde edilen ampirik ifadeleri denklem (9) ve (10)'da gösterilmiştir. 
Tablo 2. SOFC'nin elektrokimyasal modelinde kullanılan denklemler

\begin{tabular}{|c|c|c|}
\hline Denklem & Referans & Denklem no \\
\hline $2 \mathrm{H}_{2}+2 \mathrm{O}^{2-} \rightarrow 2 \mathrm{H}_{2} \mathrm{O}$ & - & (1) \\
\hline$O_{2}+4 \mathrm{e}^{-} \rightarrow 2 O^{2-}$ & - & $(2)$ \\
\hline $2 \mathrm{H}_{2}+\mathrm{O}_{2} \rightarrow 2 \mathrm{H}_{2} \mathrm{O}$ & - & (3) \\
\hline$V_{\text {cell }}=V_{\text {Nernst }}-V_{\text {act }}-V_{\text {ohm }}-V_{\text {con }}[V]$ & (Ahn vd., 2018) & (4) \\
\hline$V_{\text {Nernst }}=E^{0}-\frac{\bar{R} T}{n F} \ln \left(\frac{P_{\mathrm{H}_{2} \mathrm{O}, \text { an }}}{P_{\mathrm{H}_{2}, \text { an }} \sqrt{P_{\mathrm{O}_{2}, \text { cat }}}}\right)[V]$ & (Ahn vd., 2018) & (5) \\
\hline$E^{0}=-\frac{\Delta \bar{g}}{n F}[V]$ & (Ahn vd., 2018) & (6) \\
\hline$\Delta \bar{g}=0.002474 T^{2}+48.996 T-243.730\left[\mathrm{~J} \cdot \mathrm{mol}^{-1}\right]$ & (Ahn vd., 2018) & (7) \\
\hline$V_{a c t}=\frac{\bar{R} T}{n F} \ln \left(\frac{i^{2}}{i_{0, a n} i_{0, c a t}}\right)[V]$ & (Wu ve Bucknall, 2020) & (8) \\
\hline$i_{0, \text { cat }}=3.3 \times 10^{5}\left(\frac{P_{O_{2}}}{P_{c a t}}\right)^{0.3} \exp \left(\frac{-1.3 \times 10^{5}}{\bar{R} T}\right)\left[\mathrm{A.cm}^{-2}\right]$ & (Yonekura vd., 2011) & (9) \\
\hline$i_{0, a n}=3.5 \times 10^{2}\left(\frac{P_{H_{2}}}{P_{a n}}\right)^{0.41}\left(\frac{P_{H_{2} O}}{P_{a n}}\right)^{0.40} \exp \left(\frac{-6.2 \times 10^{5}}{\bar{R} T}\right)\left[\mathrm{A.cm}^{-2}\right]$ & (Yonekura vd., 2011) & $(10)$ \\
\hline$V_{\text {ohm }}=i\left(\rho_{a n} \delta_{a n}+\rho_{c a t} \delta_{c a t}+\rho_{e l} \delta_{e l}+\rho_{\text {int }} \delta_{\text {int }}\right)[V]$ & (Park vd., 2014) & $(11)$ \\
\hline$\rho_{a n}=2.98 \times 10^{-5} \exp \left(\frac{-1.392}{T}\right)[\Omega . m]$ & (Park vd., 2014) & $(12)$ \\
\hline$\rho_{\text {cat }}=8.114 \times 10^{-5} \exp \left(\frac{600}{T}\right)[\Omega . m]$ & (Park vd., 2014) & (13) \\
\hline$\rho_{e l}=2.94 \times 10^{-5} \exp \left(\frac{10.350}{T}\right)[\Omega . m]$ & (Park vd., 2014) & (14) \\
\hline$\rho_{\text {int }}=1.257 \times 10^{-3} \exp \left(\frac{4.690}{T}\right)[\Omega . m]$ & (Park vd., 2014) & (15) \\
\hline$V_{\text {con, } \text { cat }}=-\frac{\bar{R} T}{4 F} \ln \left(1-\frac{i}{i_{O_{2}}}\right)[V]$ & (Anyenya, 2017) & $(16)$ \\
\hline$V_{\text {con,an }}=-\frac{\bar{R} T}{2 F}\left[\ln \left(1-\frac{i}{i_{H_{2}}}\right)-\ln \left(1+\frac{i}{i_{H_{2} O}}\right)\right][V]$ & (Anyenya, 2017) & (17) \\
\hline$i_{O_{2}}=\frac{4 F P D_{\text {cat }, \text { eff }}}{\bar{R} T \delta_{\text {cat }}} \ln \left(\frac{P}{P-P_{O_{2}}}\right)\left[A / m^{2}\right]$ & (Anyenya, 2017) & (18) \\
\hline$i_{H_{2}}=\frac{2 F P_{H_{2}} D_{a n, e f f}}{\bar{R} T \delta_{a n}}\left[A / m^{2}\right]$ & (Anyenya, 2017) & (19) \\
\hline$i_{H_{2} \mathrm{O}}=\frac{2 F P_{\mathrm{H}_{2} \mathrm{O}} D_{a n, e f f}}{\bar{R} T \delta_{a n}}\left[\mathrm{~A} / \mathrm{m}^{2}\right]$ & (Anyenya, 2017) & (20) \\
\hline$D_{O, j(e f f .)}=\frac{1 \times 10^{-7} T^{1.25} \varepsilon\left(\frac{1}{M_{j}}+\frac{1}{M_{k}}\right)^{0.5}}{P \zeta\left(v_{j}^{1 / 3}+v_{k}^{1 / 3}\right)}\left[\mathrm{m}^{2} / \mathrm{s}\right]$ & (Park vd., 2014) & $(21)$ \\
\hline$D_{K, j(e f f .)}=\frac{97 r \varepsilon T^{0.5}}{\zeta M_{j}}\left[m^{2} / s\right]$ & (Park vd., 2014) & $(22)$ \\
\hline$\frac{1}{D_{j(e f f .)}}=\frac{1}{D_{O, j(e f f .)}}+\frac{1}{D_{K, j(e f f .)}}\left[\mathrm{m}^{2} / s\right]$ & (Park vd., 2014) & (23) \\
\hline$D_{a n, e f f}=\left(\frac{P_{\mathrm{H}_{2}}}{P_{a n}}\right) D_{\mathrm{H}_{2} \mathrm{O}(\text { eff. })}+\left(\frac{P_{\mathrm{H}_{2} \mathrm{O}}}{P_{\text {an }}}\right) D_{H(\text { eff. })}$ & (Park vd., 2014) & (24) \\
\hline$D_{\text {cat }, e f f}=D_{\mathrm{O}_{2}(e f f .)}$ & (Park vd., 2014) & $(25)$ \\
\hline
\end{tabular}


Direnç kayıpları elektrotların, elektrolitin ve ara bağlantı elemanlarının iç direncinden kaynaklanır ve (11-15) denklemlerinde olduğu gibi ifade edilir. Burada $e l$ ve int indisleri elektrolit ve arabağlantı elemanlarını, $\rho$ özgül özdirenci, $\delta$ bileşenin kalınlığını temsil etmektedir. Bileşenlerin kalınlığı Tablo 3'te gösterilmiştir.

Tablo 3. Yakıt pili bileşenlerinin kalınlığı (Ahn vd., 2018)

\begin{tabular}{ccc}
\hline Özellikler & Değer & Birim \\
\hline$\delta_{\text {an }}$ & 0.50 & $\mathrm{~mm}$ \\
$\delta_{\text {cat }}$ & 0.05 & $\mathrm{~mm}$ \\
$\delta_{\text {el }}$ & 0.01 & $\mathrm{~mm}$ \\
$\delta_{\text {int }}$ & 0.01 & $\mathrm{~mm}$ \\
\hline
\end{tabular}

Konsantrasyon kayıpları özellikle akım yoğunluğunun çok yüksek olduğu bölgelerde baskın olup katot ve anot için denklem (16) ve (17)'deki gibi hesaplanmıştır. Burada $i_{O_{2}}, i_{H_{2}}$ ve $i_{H_{2} O}$ sırasıyla oksijen, hidrojen ve su için limit akım yoğunluklarını temsil etmektedir. Bu malzemeler için limit akım yoğunlukları ise (18-20) denklemleri yardımıyla tespit edilmektedir. Bu denklemlerde $D_{\text {an,eff }}$ ve $D_{\text {cat,eff }}$ sırasıyla anot ve katot tarafının ikili efektif difüzyon katsayılarını temsil etmektedir. Difüzyon katsayısı, adi ve Knudsen difüzyon katsayılarının tespit edilip iki katsayının harmonik ortalamasının alınması ile hesaplanır. Bu hesaplar sırasıyla (21-25) denklemleri arasında gösterilmiştir.

Burada $O$ ve $K$ alt indisleri adi ve Knudsen difüzyon katsayılarını, $j$ ve $k$ alt indisleri malzemeleri, $M$ malzemelerin moleküler ağılıklarını, $\varepsilon$ anot ve katotun göznekliliğini, $\zeta$ anot ve katotun dolaşıklığını (tortuosity), $v$ Fuller difüzyon hacmini, $r$ anot ve katotun gözenek çapını temsil etmektedir. Difüzyon katsayılarının hesabında kullanılan parametreler Tablo 4'te verilmiştir. Gözeneklilik ve dolaşıklık Şekil 1'de görüleceği gibi ifade edilmiştir.

Tablo 4. SOFC'nin konsantrasyon kaybı hesabında kullanılan veriler (Park vd., 2014)

\begin{tabular}{ccc}
\hline Özellikler & Değer & Birim \\
\hline$r$ & 0.50 & $\mu \mathrm{m}$ \\
$\zeta$ & 6.00 & - \\
$\varepsilon_{\mathrm{an}}$ & 0.50 & $\%$ \\
$\varepsilon_{\mathrm{cat}}$ & 0.50 & $\%$ \\
$\mathrm{v}_{\mathrm{O} 2}$ & 16.60 & - \\
$\mathrm{v}_{\mathrm{N} 2}$ & 17.90 & - \\
$\mathrm{V}_{\mathrm{H} 2}$ & 7.07 & - \\
$\mathrm{V}_{\mathrm{H} 2 \mathrm{O}}$ & 12.70 & - \\
\hline
\end{tabular}

\subsection{Sistemin termodinamik olarak modellenmesi}

SOFC güç sisteminin termodinamik modeli Aspen HYSYS yazılımı yardımıyla kurulmuş olup modelin şematik diyagramı Şekil 2' de gösterilmiştir (Aspentech Inc, 2015). Şekil 2'ye göre yakıt olarak kullanılan ve 350 bar basınçta depolanan saf $\mathrm{H}_{2}, 1$ numaralı akım olarak VLV-100 poz numaralı basınç regülatöründen $1 \mathrm{~atm}$ basınçta çıkış yapmıştır. Bu basınç değeri aynı zamanda yakıt pilinin hem anot hem de katot tarafındaki çalışma basıncıdır. 5 numaralı akımda ise $25^{\circ} \mathrm{C}$ ve $1 \mathrm{~atm}$ basınçta hava temsil 
edilmiştir. Yakıt ve hava daha sonra CRV-101 poz numaralı katalitik yakıcıdan çıkan egzoz gazları ile E100 ve E-102 numaralı ön ısıtıcılardan geçerek bir miktar ısıtılmıştır. E-101 ve E-103 numaralı ISı değiştiricileri ise yakıt pilinin ıSı değiştiricilerini temsil etmekte olup yakıt pilinde gerçekleşen tepkime sayesinde ön ısıtıcıdan geçen yakıt ve havayı yeniden ısıtmaktadır. Isınan hava ve yakıt, 4 ve 7 numaralı akımlar olup bir dönüşüm reaktörü olarak modellenen CRV-100 numaralı yakıt piline yakıt pili ortalama çalışma sıcaklığının $15{ }^{\circ} \mathrm{C}$ altında giriş yapmaktadırlar (Evrin ve Dincer, 2019). Burada denklem (1), (2) ve bunların toplamı olan denklem (3)'te görülen elektrokimyasal tepkimeler sonucunda güç elde edilmektedir. Yakıt pilinin anot ve katot tarafından çıkan egzoz gazları tek bir akım halinde temsil edilerek yakıt pili ortalama çalışma sıcaklığının $15^{\circ} \mathrm{C}$ üstünde CRV-101 numaralı katalitik yakıcıya girmiş ve yakıt pilinden çıkan yanmamış $\mathrm{H}_{2}$ de yakılarak tüketilmiştir. Yanan $\mathrm{H}_{2}$ ile birlikte daha da ısınan baca gazı E-100 ve E-102 numaralı ön ısıtıcılardan geçerek atmosfere salınmaktadır. Atmosfere salınan bu gaz $\mathrm{CO}_{2}$ içermemektedir. 14 numaralı akımda ise yakıt pilinden fazla ısıyı çekerek ısıl dengeyi sağlamak amacıyla deniz suyu P-100 numaralı pompaya giriş yapmaktadır.

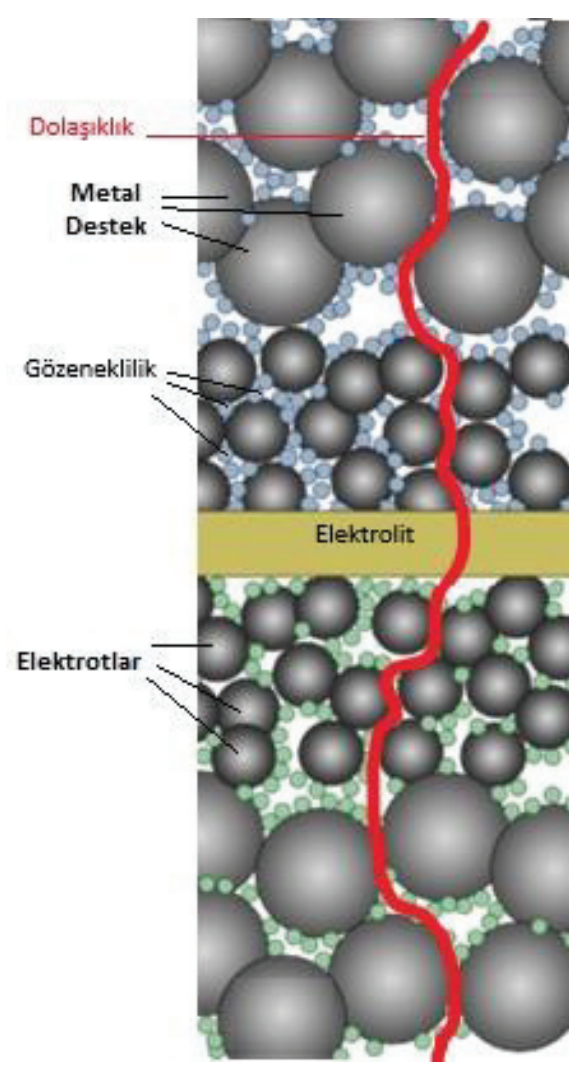

Şekil 1. Gözeneklilik ve dol aşıklığın yakıt pili yapısı üzerinde gösterimi (Dogdibegovic vd., 2019)

Burada bütün ısı değiştiricileri, katalitik yakıcı ve yakıt pilindeki basınç kayıpları ihmal edilmiştir. Ayrıca ISı değiştiricileri ve katalitik yakıcıdaki ısı kayıpları da ihmal edilmiştir (Ahn vd., 2018). Yakıt pilindeki ISı kaybı ise yakıt pilinde elde edilen toplam enerjinin \%5'i kabul edilmiştir (Anyenya, 2017). Yakıt pilinin ısı değiştiricilerinde pinç noktası sıcaklık farkı $30 \mathrm{~K}$ olup diğer ısı değiştiricilerinde minimum 15 K'dir (Evrin ve Dincer, 2019; Nordin ve Majid, 2016). Pompa için verim \%90 alınmıştır (Park vd., 2014). Deniz suyu pompa giriş sıcaklığı en kritik sıcaklık olan $32{ }^{\circ} \mathrm{C}$ ve çıkış sıcaklığı $37^{\circ} \mathrm{C}$ alınmıştır (Bureau Veritas, 2020). Malzemelerin termodinamik özelliklerinin belirlenmesinde Peng-Robinson denklem takımı kullanılmıştır (Peng ve Robinson, 1976).

Sistem elemanlarının güç ve termodinamik denklemleri ise Tablo 5'de gösterilmiştir. Burada $D C-A C$, in, out, isen, loss, pump, $H E X, a, b$, net, th, sys indisleri sırasıyla doğru akımdan alternatif akıma 
dönüştürülmeyi, giren ve çıkan akımları, izentropik durum değişimini, kaybı, pompayı, ısı değiştiricisini, ISı değiştiricisinin sıcak ve soğuk taraflarını, toplamı termal verimi, ve sistemi temsil etmektedir. $A_{\text {cell }}$, $\eta, \dot{m}, h, \dot{Q}, \dot{W}, L H V$ parametreleri ise sırasıyla toplam SOFC aktif hücre alanını, verimi, kütle debisini, entalpiyi, birim zamanda iletilen ısıyı, gücü ve alt ısıl değeri temsil etmektedir.

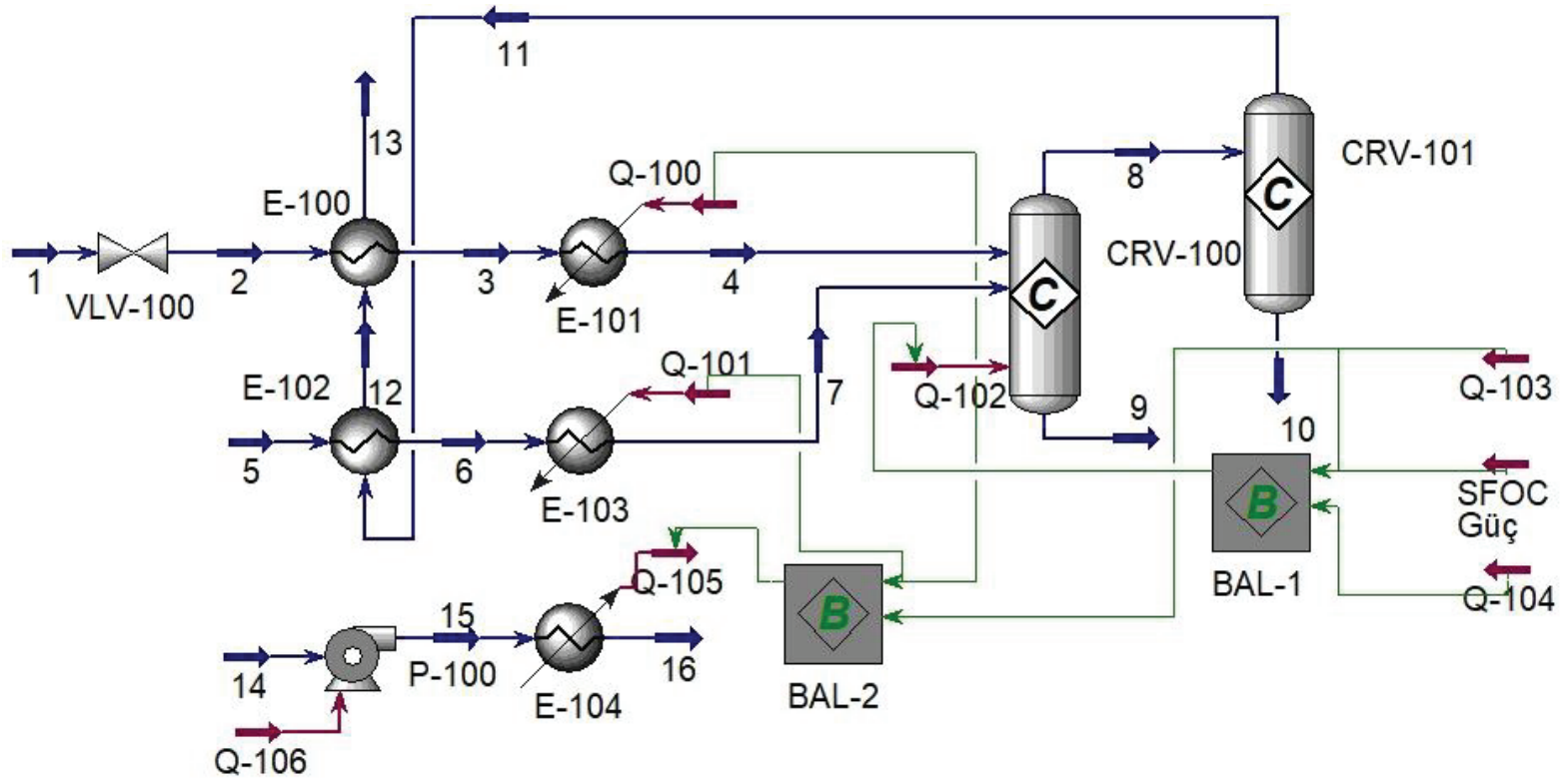

Şekil 2. SOFC güç çevriminin şematik modeli

Tablo 5. SOFC güç çevriminin termodinamik modelinin denklemleri

\begin{tabular}{|c|c|}
\hline Denklem & Denklem no \\
\hline$\dot{W}_{S O F C}=i . A_{\text {cell }} \cdot V_{\text {cell }} \cdot \eta_{D C-A C}[W]$ & (26) \\
\hline $\begin{array}{l}\dot{W}_{\text {SOFC }}=\left(\dot{m}_{a n, i n} \cdot h_{a n, \text { in }}-\dot{m}_{\text {an }, \text { out }} \cdot h_{\text {an }, \text { out }}\right) \\
\quad+\left(\dot{m}_{\text {cat }, \text { in }} \cdot h_{\text {cat }, \text { in }}-\dot{m}_{\text {cat }, \text { out }} \cdot h_{\text {cat }, \text { out }}\right)-\dot{Q}_{\text {loss }}[W]\end{array}$ & $(27)$ \\
\hline$\dot{W}_{\text {pump }}=\dot{m}\left(h_{\text {out }, \text { ideal }}-h_{\text {in }}\right) \eta_{\text {isen,pump }}[W]$ & (28) \\
\hline$\dot{Q}_{H E X}=\dot{m}_{a}\left(h_{a, \text { out }, \text { ideal }}-h_{a, \text { in }}\right)=\dot{m}_{b}\left(h_{b, \text { out }, \text { ideal }}-h_{b, \text { in }}\right)[W]$ & (29) \\
\hline$\dot{W}_{\text {net }}=\dot{W}_{\text {SOFC }}-\dot{W}_{\text {pump }}[W]$ & (30) \\
\hline$\eta_{t h, s y s}=\dot{W}_{n e t} /\left(\dot{m}_{\mathrm{H}_{2}} \cdot L H V_{\mathrm{H}_{2}}\right)$ & $(31)$ \\
\hline
\end{tabular}

\section{Sistemin Ekonomik Analizi}

Bu çalışmada sistemin ekonomik analizi gemiler için yapılan önceki çalışmalardan farklı olarak azaltılan birim $\mathrm{CO}_{2}$ miktarına bağlı olacak şekilde gerçekleştirilmiştir. Böylece elde edilen sonuçlar diğer $\mathrm{CO}_{2}$ emisyonu azaltma yöntemleriyle daha gerçekçi bir şekilde karşılaştırılabilecektir. Azaltılan birim $\mathrm{CO}_{2}$ başına maliyet, belirlenen referans gemi ve güç kaynağı olarak buna uygun seçilen dizel yakıtlı jeneratörlerin değiştirilip yerine bu jeneratörlerin ortalama çalışma yükünü sağlayan SOFC güç sisteminin kullanılmasından kaynaklanan maliyet artışı ve atmosfere salınan $\mathrm{CO}_{2}$ miktarının azalışı verilerinden tespit edilmiştir. Hem referans geminin önceki güç çevriminin hem de yeni güç çevriminin yıllık toplam maliyetleri, toplam yaşam döngüsü maliyetlerinin geminin çalışma ömrüne bölünmesiyle elde edilmiştir. Toplam yaşam döngüsünün maliyetlerini ise yakıt maliyetleri ve ilk yatırım maliyetleri 
oluşturmaktadır. İşçilik maliyetlerinin her iki senaryoda da yakın değerlerde olacağı ve bakım-tutumonarım maliyetlerinin toplam yaşam maliyeti üzerinde etkisinin küçük olacağı düşünülmüştür. Bu nedenle yakıt maliyetleri dışındaki, bakım-tutum-onarım maliyetleri ile işçilik maliyetleri gibi diğer işletme maliyetlerinin etkisi dikkate alınmamıştır (Park vd., 2014).

Yakıt pillleri malzeme faz değişimi, ürün ayrışması, mikroyapısal değişiklikler, kırılma, hücrede kompozit yapıda bulunan malzemelerin ayrışması, membrandaki zehirlenme, nemlilik, safsızlıklar, oksitlenme gibi sebeplerle zamanla kimyasal olarak bozulmaya uğrayabilir. Gemiler için yapılan önceki çalışmalardan farklı olarak bu çalışmada yakıt pilinin kimyasal bozulması sebebi ile potansiyelinin düşüşü de dikkate alınmıştır. Potansiyeldeki bu düşüş elde edilen gücü azaltacaktır. Bu durumun önüne geçmek için yakıt pili kaybolan gücü de temin edecek şekilde seçilmiştir. Dolayısıyla artan SOFC ilk yatırım ve yakıt maliyetleri de bu çalışmada göz önüne alınmıştır. Yakıt pili çalışma ömrü sonunda kimyasal bozulmadan kaynaklanan potansiyel kaybı aşağıdaki denklem yardımıyla tespit edilir:

$$
\text { Potansiyel kaybl }=100 \times\left(1-r_{d} / 100\right)^{t / 1000}[\%]
$$

Burada $r_{d}$ SOFC yakıt pili için bin saatteki yüzdelik potansiyel kaybı, $t$ ise seçilen SOFC çalışma ömrünü temsil etmekte olup bu değerler Tablo 6 'da gösterilmiştir. Güç çevrimlerinin ilk yatırım maliyetleri ise ekipmanların satın alma maliyetlerinin bir faktör ile çarpılmasından tespit edilmiştir. Ayrıca ekipmanların ilk yatırım maliyeti hesaplanırken borçlanmadan kaynaklanacak faiz de dikkate alınmıştır. Vergiler ve sigorta ücretleri ise dikkate alınmamıştır. Ekonomik analiz ile ilgili kabuller Tablo 6'da, ekipman satın alma ücretlerinin literatürden tespit edilen denklemleri ise Tablo 7'de gösterilmiştir.

Tablo 6. Ekonomik analiz için yapılan kabuller

\begin{tabular}{|c|c|c|c|}
\hline Özellikler & Değer & Birim & Referans \\
\hline Potansiyel kaybı & 0.75 & $\% / 1000$ saat & (Sohal, 2009) \\
\hline Seçilen SOFC çalışma ömrü & 50,000 & saat & (Zhang vd., 2010) \\
\hline Dizel yakıt fiyatı & 550 & USD/ton & (Ship\&Bunker, 2021) \\
\hline $\mathrm{H}_{2}$ yakıt fiyatı & $3,500 *$ & USD/ton & $\begin{array}{l}\text { (Wu ve Bucknall, } \\
\text { 2020) }\end{array}$ \\
\hline Gemi toplam yaşam ömrü & 25 & yıl & (Luo ve Wang, 2017) \\
\hline Yıllık çalışma süresi & 5000 & saat & Bu çalışma \\
\hline $\begin{array}{l}\text { Dizel jeneratörlerin ortalama } \\
\text { çalışma yükünün nominal yüke } \\
\text { oranı }\end{array}$ & 55 & $\%$ & (Aijjou vd., 2019) \\
\hline $\begin{array}{l}\text { Ölçülen ortalama yakıt tüketiminin } \\
\text { ürün kataloğundaki tüketime oranı }\end{array}$ & 123.8 & $\%$ & (Aijjou vd., 2019) \\
\hline Toplam ilk yatırım maliyet faktörü & 2.5 & & (Costa vd., 2011) \\
\hline Faiz oranı (ir) & 4 & $\% / y ı l$ & (Luo ve Wang, 2017) \\
\hline
\end{tabular}

Tablo 7'de verilen $C E P C I_{r}, f_{M}, f_{P}$ ve $f_{T}$ sırasıyla kimya mühendisliği tesis maliyet indeksinin 2020'deki değerinin referans yıldaki değerine oranını, malzeme faktörünü, basınç faktörünü ve sıcaklık faktörünü temsil etmektedir. Bu faktörler Tablo 8'de verilmiş olup bütün Isı değiştiricilerinde düşük dereceli 
paslanmaz çelik (SS) kullanılması öngörülmüştür (Hackl ve Harvey, 2013). CEPCI $I_{r}$ değerleri referans yıllarına göre pompalar, ısı değiştiricileri, dizel jenaratör, dönüştürücü ve SOFC için sırasıyla 584, 391, 567 ve 394 olarak tespit edilmiştir (Shirmohammadi vd., 2021). CEPCI değeri 2020 yılı için 594 olup bu bilgiler doğrultusunda $C E P C I_{r}$ değerleri her bir ekipman için ayrı ayrı tespit edilmiştir (Shirmohammadi vd., 2021). Dizayn basıncı çalışma basıncının 1.5 katı olarak kabul edilmiş, $500{ }^{\circ} C^{\prime}$ nin üstündeki sıcaklıklarda çalışan ısı değiştiricileri için de sıcaklık faktörü 2.1 olarak alınmıştır (Bureau Veritas, 2020). Yakıt depolama tankı ile katalitik yakıcının maliyetleri ise dikkate alınmamıştır.

Tablo 7. Ekipmanların satın alma maliyetleri

\begin{tabular}{lccc}
\hline Ekipmanlar & Denklem & Referans & Denklem no \\
\hline Pompa & $C_{\text {pump }}=3.500 \dot{W}_{\text {pump }}^{0.45} \cdot C E P C I_{r, p u m p}$ & (Ganjehkaviri ve Jaafar, 2014) & (33) \\
Isı değiştiricisi & $C_{H E X}=32.800\left(\frac{A_{H E X}}{80}\right) \cdot C E P C I_{r, H E X} \cdot f_{M} \cdot f_{P} \cdot f_{T}$ & (Hackl ve Harvey, 2013) \\
Dizel jeneratör & $C_{D E}=1.013 \dot{W}_{D E}^{0.8} \cdot C E P C I_{r, D E .}$. & (Fioriti vd., 2017) \\
$\begin{array}{l}\text { Dönüştürücü } \\
\text { (inverter) } \\
\text { SOFC }\end{array}$ & $C_{I}=10^{5}\left(\dot{W}_{\text {total }} / 500\right)^{0.7} \cdot C E P C I_{r, I .}$. & (Park vd., 2014) \\
\hline
\end{tabular}

Tablo 8. Isı değiştiricisi maliyet hesabında kullanılan malzeme, basınç, sıcaklık faktörleri (Hackl ve Harvey, 2013)

\begin{tabular}{lc|cc|cc}
\hline Malzeme & Faktör $\left(\mathrm{f}_{\mathrm{M}}\right)$ & Basınç $($ bar $)$ & Faktör $\left(\mathrm{f}_{\mathrm{P}}\right)$ & Sıcaklık $\left({ }^{\circ} \mathrm{C}\right)$ & Faktör $\left(\mathrm{f}_{\mathrm{T}}\right)$ \\
\hline CS & 1.0 & $0.01-0.1$ & 2.0 & $0-100$ & 1.0 \\
Düşük dereceli SS & 2.1 & $0.1-0.5$ & 1.3 & $100-300$ & 1.6 \\
Yüksek dereceli SS & 3.2 & $0.5-7$ & 1.0 & $300-500$ & 2.1 \\
Monel & 3.6 & $7-50$ & 1.5 & & \\
Inkomel & 3.9 & $50-100$ & 1.9 & & \\
Nikel & 5.4 & & & & \\
Titanyum & 7.7 & & & & \\
LTCS & 1.5 & & & & \\
\hline
\end{tabular}

Tablo 7'ye göre ısı değiştiricilerinin maliyetini bulmak için ısı değiştiricilerinin yüzey alanlarının tespit edilmesi gerekmektedir. Yüzey alanları ise aşă̆ıdaki denklemler yardımıyla tespit edilir (Hackl ve Harvey, 2013):

$$
\begin{gathered}
Q_{H E X}=U \cdot A_{H E X} \cdot \Delta T_{m}[W] \\
\Delta T_{m}=F_{t} \cdot \Delta T_{l m}[K] \\
\Delta T_{l m}=\frac{\left(T_{1}-t_{2}\right)-\left(T_{2}-t_{1}\right)}{\ln \frac{\left(T_{1}-t_{2}\right)}{\left(T_{2}-t_{1}\right)}}[K] \\
-97-
\end{gathered}
$$




$$
\begin{gathered}
F_{t}=\frac{\sqrt{\left(R^{2}+1\right)} \ln \frac{(1-S)}{(1-R \cdot S)}}{(R-1) \ln \frac{2-S\left(R+1-\sqrt{\left(R^{2}+1\right)}\right)}{2-S\left(R+1+\sqrt{\left(R^{2}+1\right)}\right)}} \\
S=\frac{\left(t_{2}-t_{1}\right)}{\left(T_{1}-t_{1}\right)} \\
R=\frac{\left(T_{1}-T_{2}\right)}{\left(t_{2}-t_{1}\right)}
\end{gathered}
$$

Burada $U, F_{t}, \Delta T_{l m}, T_{1}, T_{2}, t_{1}$ ve $t_{2}$ sırasıyla toplam ısı transfer katsayısını, gövde-boru tipli ve karşıt akışlı bir ısı değiştiricisi için doğrulama faktörünü, sıcaklık farkının logaritmik ortalamasını, ıSı değiştiricisi girişindeki sıcak akışkanın sıcaklığını, çıkıştaki sıcak akışkanın sıcaklığını, girişteki soğuk akışkanın sıcaklığını ve çıkıştaki soğuk akışkanın sıcaklığını temsil etmektedir.

Illk yatırım maliyetinin (CAPEX) faiz etkisiyle yıllık ödeme miktarı, sermaye dönüşüm faktörü (CRF) yardımıyla hesaplanır. Yıllık ilk yatırım maliyeti miktarı (ACAPEX) ve CRF aşağıdaki denklemler yardımıyla hesaplanmıştır (Güler ve Ergin, 2021):

$$
\begin{gathered}
C R F=\frac{\operatorname{ir}(i r+1)^{n}}{(i r+1)^{n}-1} \\
A C A P E X=C A P E X . C R F \text { [milyon USD] }
\end{gathered}
$$

Burada $n$ SOFC için pilin yıllık ömrü olup Tablo 6 'da verilen saatlik çalışma ömrü ile yıllık çalışma süresi verilerinden 10 yıl olarak hesaplanmış ve diğer ekipmanlar için geminin çalışma ömrü olan 25 yıl olarak kabul edilmiştir.

\section{Bulgular ve Tartışma}

SOFC çalışma sıcaklığı ve akım yoğunluğunun pil potansiyeli ve güç yoğunluğu üzerine etkisi Şekil 3'te gösterilmiştir. Pil potansiyeli literatüre uygun bir şekilde direnç ve etkinleşme kayıplarının etkisiyle artan akım yoğunluğuna bağlı olarak giderek azalmış ve limit akım yoğunluğuna yaklaşınca aniden düşmüştür (Sohal, 2009). Düşük akım yoğunluklarında pil potansiyelinin değeri, düşük sıcaklık değerlerinde çalışan yakıt pilleri için daha yüksektir. Ancak akım yoğunluğu arttıkça yüksek sıcaklıkta çalışan yakıt pilleri, pil potansiyeli açısından daha avantajıdır. Bu durum etkinleşme kayıplarının yüksek sıcaklarda etkili olabilmesi için düşük sıcaklıklara kıyasla daha yüksek akım yoğunluğu gerektirmesinden kaynaklanır. Örneğin çalışma sıcaklığı $1173 \mathrm{~K}$ olan yakıt pilinde etkinleşme kaybının etkili olmaya başladığı akım yoğunluğu 2,800-3,000 A/m² civarında iken $973 \mathrm{~K}$ çalışma sıcaklı̆̆ında 300-500 A/m² civarındadır. Güç yoğunluğu ise artan akımla birlikte bütün sıcaklık değerlerinde konsantrasyon kaybının etkili olmaya başladığı bölgeye kadar pik yapar ve daha sonra pil potansiyelinde olduğu gibi aniden düşer.

Pil potansiyeli sistemin verimini, dolayısıyla kullanılacak yakıt miktarı ve yakıt maliyetini etkiler. Güç yoğunluğu ise SOFC'nin alanını ve dolayısıyla ilk yatırım maliyetini belirler. Buna göre akım yoğunluğunun artışı yakıt maliyetini artırırken SOFC'nin ilk yatırım maliyetini azaltacaktır. Böylece seçilen çalışma sıcaklığı için maliyeti minimize eden bir akım değeri olacaktır. Sıcaklık için durum biraz daha farklı olup artan sıcaklık ile gereken pil alanı ve ilk yatırım maliyeti yine azalacak ancak kullanılan 
ISSN: 1300-1973, e-ISSN: 2651-530X, Journal homepage: http://www.gmoshipmar.org/

malzemelerin sıcaklığa daha mukavim ve daha zor üretilebilir olması ilk yatırım maliyetini artıracaktır. Sıcaklığın ilk yatırım maliyeti üzerindeki etkisi denklem (36)'da gösterilmiştir. Ayrıca sıcaklığın elde edilebilecek potansiyel üzerindeki etkisi seçilen akım yoğunluğuna bağlı olarak da değişkenlik göstermektedir.

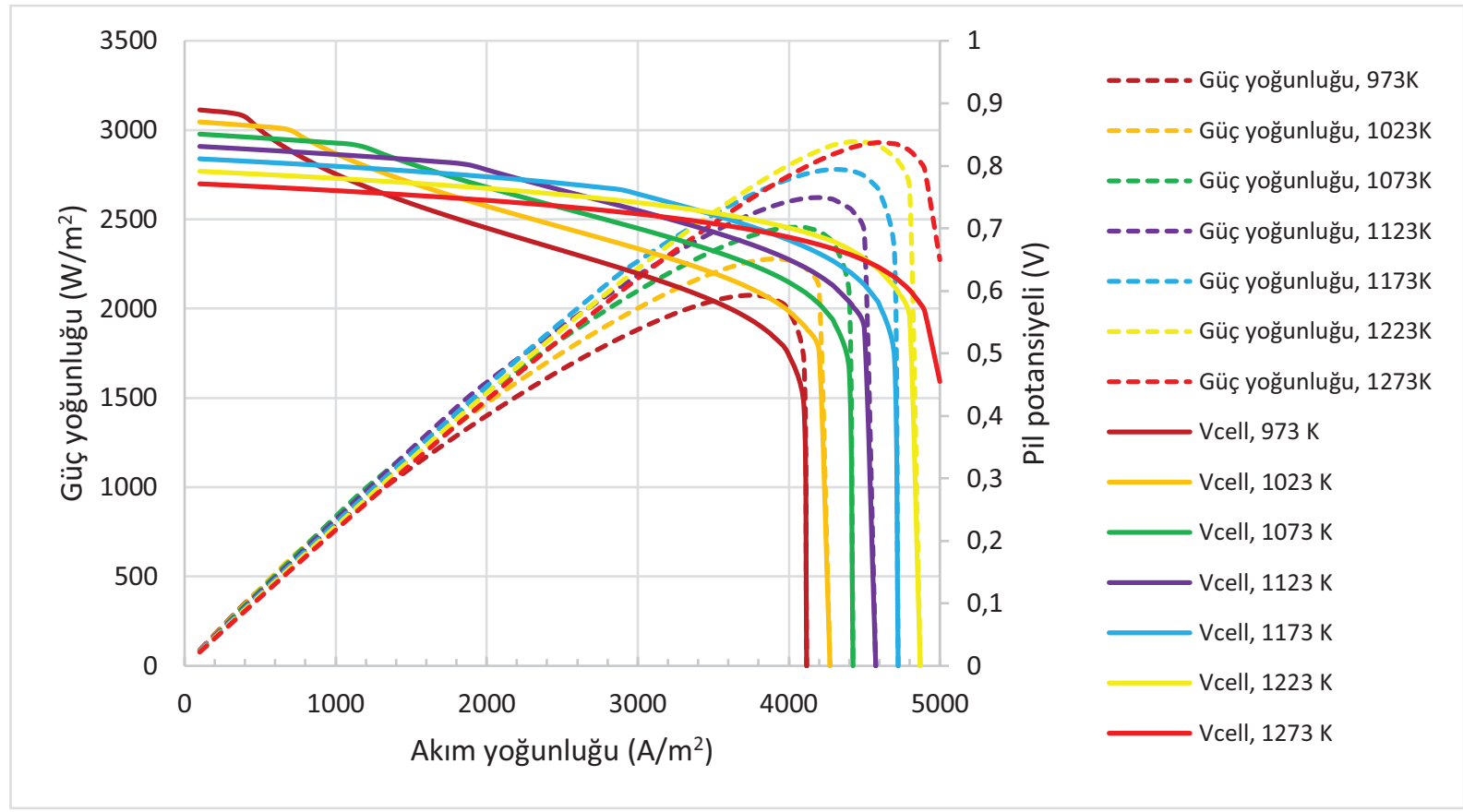

Şekil 3. SOFC çalışma sıcaklığı ve akım yoğunluğunun pil potansiyeli ve güç yoğunluğu üzerine etkisi

Bu bulgular sonucunda sistemin maliyetini minimize eden SOFC akım yoğunluğu ve sıcaklığı parametrik bir çalışma ile tespit edilmiştir. Akım yoğunluğunun ve sıcaklığın $\mathrm{CO}_{2}$ azaltma maliyeti üzerine etkisi sırasıyla Şekil 4 ve 5 'te gösterilmiştir.

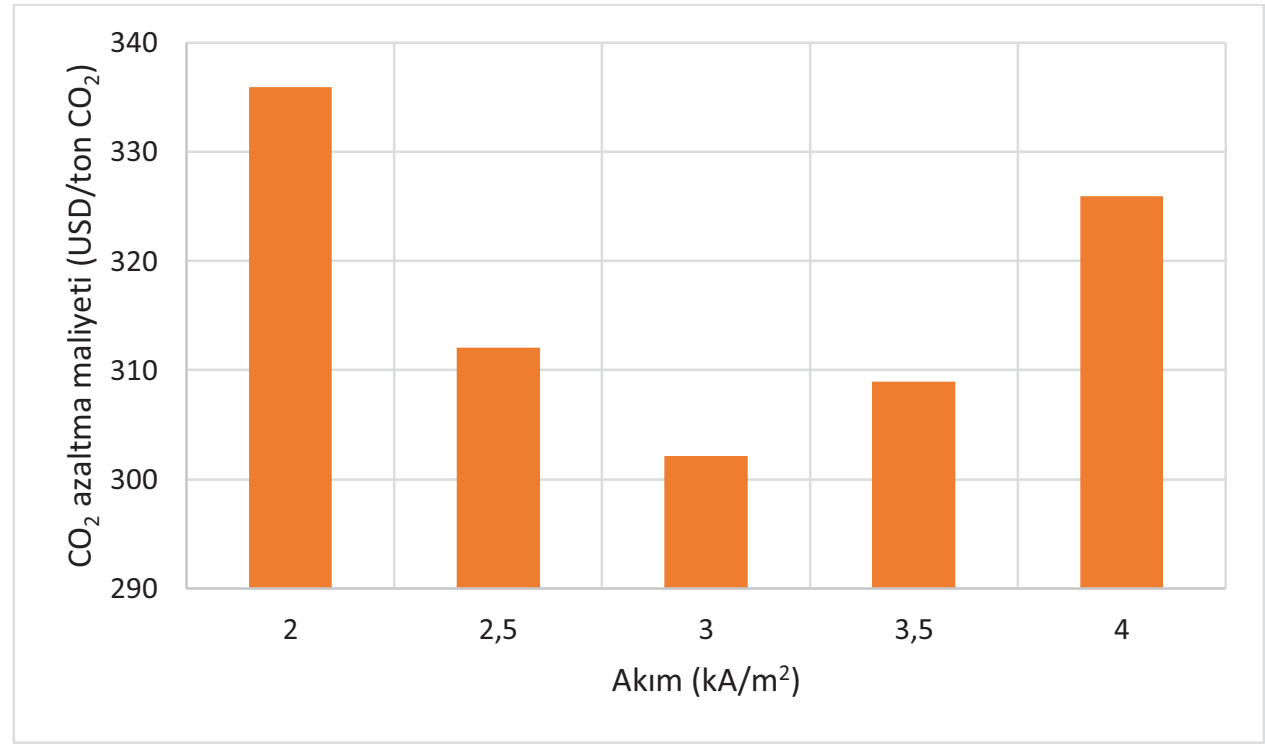

Şekil 4. SOFC akım yoğunluğunun $\mathrm{CO}_{2}$ azaltma maliyeti üzerine etkisi

Akım yoğunluğu için 2-4 kA/m² aralığı incelenmiş olup Şekil 4'e göre maliyet açısından en uygun akım değeri $3 \mathrm{kA} / \mathrm{m}^{2}$ değeri olmuştur. Literatürde seçilen çalışma akım yoğunlukları $3-5 \mathrm{kA} / \mathrm{m}^{2}$ olup sonuç 
literatürle uyumludur (Ahn vd., 2018; Anyenya, 2017; Park vd., 2014). Burada seçilen çalışma sıcaklığı ise $1173 \mathrm{~K}^{\prime}$ dir.

Sıcaklık içinse 973-1273 K aralığı incelenmiş olup Şekil 5’e göre en uygun sıcaklık değeri $1173 \mathrm{~K}$ olarak bulunmuştur. Burada seçilen akım yoğunluğu ise $3 \mathrm{kA} / \mathrm{m}^{2 \prime}$ dir. Akım yoğunluğundan farklı olarak burada birim $\mathrm{CO}_{2}$ azaltma maliyeti parabolik bir eğri yerine dalgalanma göstermiştir. Bu durum daha önce de belirtildiği üzere artan sıcaklık ile ihtiyaç duyulan SOFC yüzey alanının azalması, malzeme değerinin artması ve elde edilen potansiyelin değişkenlik göstermesinden kaynaklanır. Elde edilen potansiyel farklı sıcaklıklar için $\mathrm{V}_{973 \mathrm{~K}}<\mathrm{V}_{1023 \mathrm{~K}}<\mathrm{V}_{1073 \mathrm{~K}}<\mathrm{V}_{1273 \mathrm{~K}}<\mathrm{V}_{1123 \mathrm{~K}}<\mathrm{V}_{1223 \mathrm{~K}}<\mathrm{V}_{1173 \mathrm{~K}}$ şeklindedir. Sonuç olarak incelenen koşullarda akım yoğunluğunun seçimi birim $\mathrm{CO}_{2}$ azaltma maliyetini \%10.0'a, sıcaklığın seçimi ise birim $\mathrm{CO}_{2}$ azaltma maliyetini \%26.1'e kadar azaltmıştır.

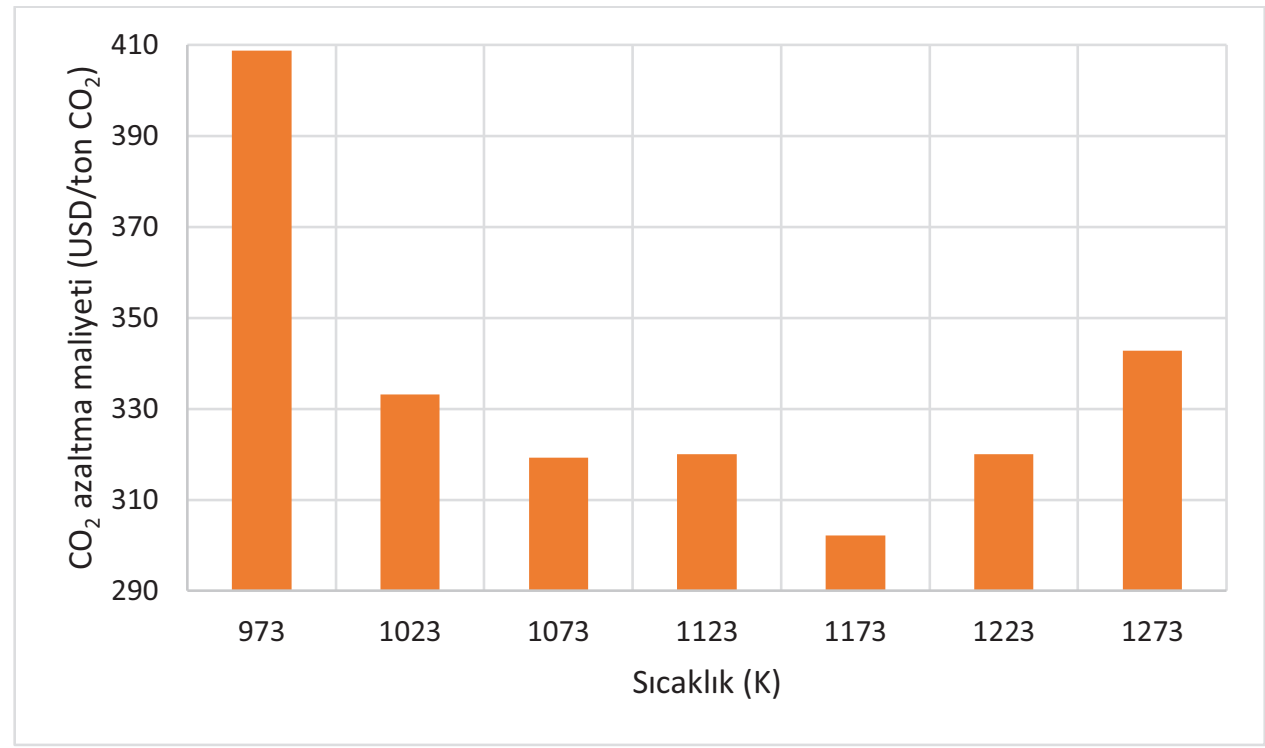

Şekil 5. SOFC sıcaklığının $\mathrm{CO}_{2}$ azaltma maliyeti üzerine etkisi

$1173 \mathrm{~K}$ çalışma sıcaklığı ve $3 \mathrm{kA} / \mathrm{m}^{2}$ akım yoğunluğundaki SOFC güç sistemi için $\mathrm{CO}_{2}$ azaltma maliyeti 302.2 USD/ton $\mathrm{CO}_{2}$ olup literatürde çeşitli gemi tipleri için $\mathrm{H}_{2}$ yakıtlı yakıt pilleri için bu değerler 1.000 USD/ton $\mathrm{CO}_{2}$ 'in üstündedir (Lloyd's Register, 2018). Üstelik referans çalışmada ekipman maliyetinde önemli yere sahip olan faiz oranı yalnızca \%1 kabul edilmiştir. Referans çalışmada seçilen yakıt pilinin tipi, çalışma koşulları vs. bilinmemekle birlikte bu çalışmada hesaplanan maliyet literatüre göre oldukça düşüktür. Yine aynı çalışmada yakıt olarak $\mathrm{NH}_{3}$ 'ün kullanıldığı yakıt pilleri için bu maliyet $700-800$ USD/ton $\mathrm{CO}_{2}$ civarındadır. Referans olarak kullanılan çalışmada incelenen elektrik, tek başına veya hibrit $\mathrm{H}_{2}$ yakıtlı içten yanmalı makine, tek başına veya hibrit $\mathrm{NH}_{3}$ yakıtlı içten yanmalı makine, biyoyakıt gibi sıfır emisyonlu diğer teknoloji ve yöntemler arasında en ucuz maliyete sahip olduğu tespit edilen yöntem biyoyakıt kullanımı olup maliyeti hem $\% 1$ hem de $\% 10$ faiz oranları için 250 USD/ton $\mathrm{CO}_{2}$ civarındadır. Bu çalışmadan elde edilen sonuçlar SOFC güç sisteminin biyoyakıt kullanımı hariç karşılaştırılan diğer karbondioksit emisyon azaltım yöntemlerinden daha ucuz olduğunu göstermektedir. 3,000 kW güce sahip sıvılaştırılmıs doğal gaz yakıtı bir makine için uygulanan ve \%90 oranında tutum sağlayan bir karbon tutum ve depolama sisteminin (CCS) maliyeti ise $98 € /$ ton $\mathrm{CO}_{2}$ olup bu çalışmada elde edilen sonuçlara göre maliyet açısından çok daha iyidir (Feenstra vd., 2019). Ayrıca $\mathrm{CO}_{2}$ emisyonlarını azaltmada etkili bir diğer yöntem olan hız düşürme yöntemi IMO'nun gelecekteki $\mathrm{CO}_{2}$ emisyonları hedeflerini sağlayabilmekte, hatta bazı gemi tipleri ile yakıt ve navlun koşulları için maliyet yerine kar bile getirebilmektedir (Güler ve Ergin, 2021). Avrupa'daki karbon vergisi fiyatları ise 2021 yılı şubat ayı itibari ile $40 €$ /ton $\mathrm{CO}_{2}{ }^{\prime} \mathrm{i}$ geçmişstir (Buli ve Abnett, 2021). Gelecekte bu fiyatların daha 
da artacağı öngörülse de bugünün fiyatlarıyla çalışmada önerilen güç sistemini kullanmak yerine karbon vergisi ödemek işletmeciler için maliyet açısından daha cazip görünmektedir (Lloyd's Register, 2018). Bu sonuçlarla birlikte değerlendirildiğinde yakıt pillerinin maliyetlerinin azaltılması yönünde daha fazla gelişime ihtiyaç duyulduğu görülmektedir.

$1173 \mathrm{~K}$ çalışma sıcaklığı ve $3 \mathrm{kA} / \mathrm{m}^{2}$ akım yoğunluğundaki SOFC güç sisteminin toplam termal verimi, sistem sayesinde azaltılan $\mathrm{CO}_{2}$ emisyon oranı, sistemin toplam yıllık maliyeti ile referans geminin güç sisteminin verimi ve toplam yıllık maliyeti (ATC) Tablo 9'da SOFC ömrü başlangıç (1 alt indisi) ve bitiş koşulları (2 alt indisi) için gösterilmiştir. Tabloda toplam yıllık maliyete daha önce de belirtildiği üzere kimyasal bozulmadan kaynaklı verim kaybını telafi eden ek yakıt maliyeti de dahil edilmiştir.

Literatürde kimyasal bozulmanın ihmal edildiği benzer çalışma koşullarına sahip bir SOFC-GT hibrit sisteminin toplam termal verimi \%61.31 olup bu çalışmada kimyasal bozulmanın etkisinin olmadığı durumda ise toplam termal verim \%51.05'tir (Ahn vd., 2018). Aradaki bu farkın temel sebebi bu çalışmada elde edilen atık ısının GT veya benzeri bir güç üretim sistemi ile atık ısının değerlendirilmemesidir. Koster oldukça küçük bir gemi tipi olup GT gibi ekipmanların güç üretim sistemlerine entegrasyonu hacim ve alan sınırlamaları nedeniyle oldukça güçtür. Ancak daha büyük tipteki gemilerin ana makinelerinin de dahil edildiği kombine güç sistemleri ile bu verim çok daha yüksek olacaktır. Referans çalışmanın koşulları ile gerçekleştirilen validasyon sonucunda hesaplanan güç yoğunluğu değeri referans çalışmadan $\% 4.68$ farklılık göstermekte olup bu fark kabul edilebilir düzeydedir. Tablo 9'a göre kimyasal bozulma etkisiyle sistemin toplam verimi \%29.38 azalmıştır. SOFC güç sisteminin termal verimi her iki koşulun aritmetik ortalaması kabul edilecek olursa $\% 43.58$ olacaktır. Bu durumda sistemin verimi geminin referans yardımcı güç sisteminin veriminden \%20.7 daha fazladır. Azaltılan $\mathrm{CO}_{2}$ miktarı ise gemiden salınan toplam $\mathrm{CO}_{2}$ miktarının \%24.27'si kadar olmuştur. Sadece yardımcı güç sistemini SOFC olarak değiştirmek bile $\mathrm{CO}_{2}$ emisyonlarının büyük ölçüde azalmasını sağlamıştır.

Tablo 9. $1173 \mathrm{~K}$ çalışma sıcaklığı ve $3 \mathrm{kA} / \mathrm{m}^{2}$ akım yoğunluğundaki SOFC ile referans güç sisteminin sonuçları

\begin{tabular}{lcc}
\hline Özellikler & Değer & Birim \\
\hline$\eta_{\mathrm{th}, 1}$ & 51.05 & $\%$ \\
$\eta_{\mathrm{th}, 2}$ & 35.04 & $\%$ \\
$\eta_{\mathrm{th}, \mathrm{DE}}$ & 36.11 & $\%$ \\
$\mathrm{CO}_{2}$ azaltımı & 24.27 & $\%$ \\
$\mathrm{ATC}_{\mathrm{SOFC}}$ & 775.3 & k USD \\
ATC $_{\mathrm{DE}}$ & 321.3 & k USD \\
\hline
\end{tabular}

$1173 \mathrm{~K}$ çalışma sıcaklığı ve $3 \mathrm{kA} / \mathrm{m}^{2}$ akım yoğunluğundaki SOFC güç sistemi ile geminin referans güç sisteminin maliyet bileşenleri yüzdelik olarak Şekil 6 ve Şekil 7'de gösterilmiştir. Her iki şekil için de maliyetin en büyük kaynağının yakıt olduğu görülmektedir. Şekil 6'ya göre $\mathrm{H}_{2}{ }^{\prime}$ nin maliyeti toplam maliyetin \%65.28'ini oluşturmaktadır. Sistemin birim $\mathrm{CO}_{2}$ azaltma miktarı başına maliyeti incelendiğinde ise yakıt maliyetinin toplam maliyetin \%47.42'sini oluşturduğu hesaplanmıştır. Aradaki fark referans güç sistemindeki yakıt maliyetinin de yüksek olmasıyla ilgilidir.

H2'nin maliyetini artıran en büyük unsurlardan birisi sıkıştırma, depolama ve dağıtım (CSD) maliyeti olup bu maliyet 850-1.350 kg/günlük kapasite koşullarında çeşitli taşıma araçları için 1.10-2.70 USD/kg 
arasında değişmektedir (Parks vd., 2014). Bugünün koşullarında günlük taşıma kapasitesi düşük olup gelecekte kapasitenin artmasıyla maliyetin düşmesi beklenmektedir. H2'nin üretim maliyeti ise üretim kaynağına bağlı olmakla birlikte günümüzde 0.95-3.5 USD/kg arasında değişkenlik göstermektedir (Birol, 2019; Gielen ve Taibi, 2019). Yapılabilecek yığın üretim ve ekipman maliyetlerindeki düşüş sayesinde elektroliz yöntemiyle 2040 yılına kadar sıfır CO2 emisyonlu üretim maliyetinin 3.5'tan 1.41.5 USD/kg civarlarına kadar düşmesi beklenmektedir (Gielen ve Taibi, 2019; Giers vd., 2020). Maliyeti artıran en büyük ikinci faktör ise yakıt pili ilk yatırım maliyetidir. Bu maliyeti güç yoğunluğu, sıcaklığa göre seçilen malzeme değeri gibi faktörler etkilese de maliyetin en büyük kaynağı kimyasal bozulma dolayısıyla pilin çalışma ömrüdür. Üstelik bu kimyasal bozulmanın azalışı sistemin verimini artıracak, dolayısıyla güç telafisinde kullanılan dizel yakıtın maliyetini ve atmosfere salınan $\mathrm{CO} 2$ emisyon miktarını da azaltacaktır. Bu çalışmada kullanılan SOFC'nin kimyasal bozulmadan kaynaklı kaybı 1.000 saatte 6 $\mathrm{mV}$ yerine yalnızca $1 \mathrm{mV}$ ve buna göre seçilen SOFC ömrü gemi ile eşdeğer olsaydı SOFC güç sisteminin birim $\mathrm{CO} 2$ azaltma maliyeti \%14.08 daha az olacaktı.

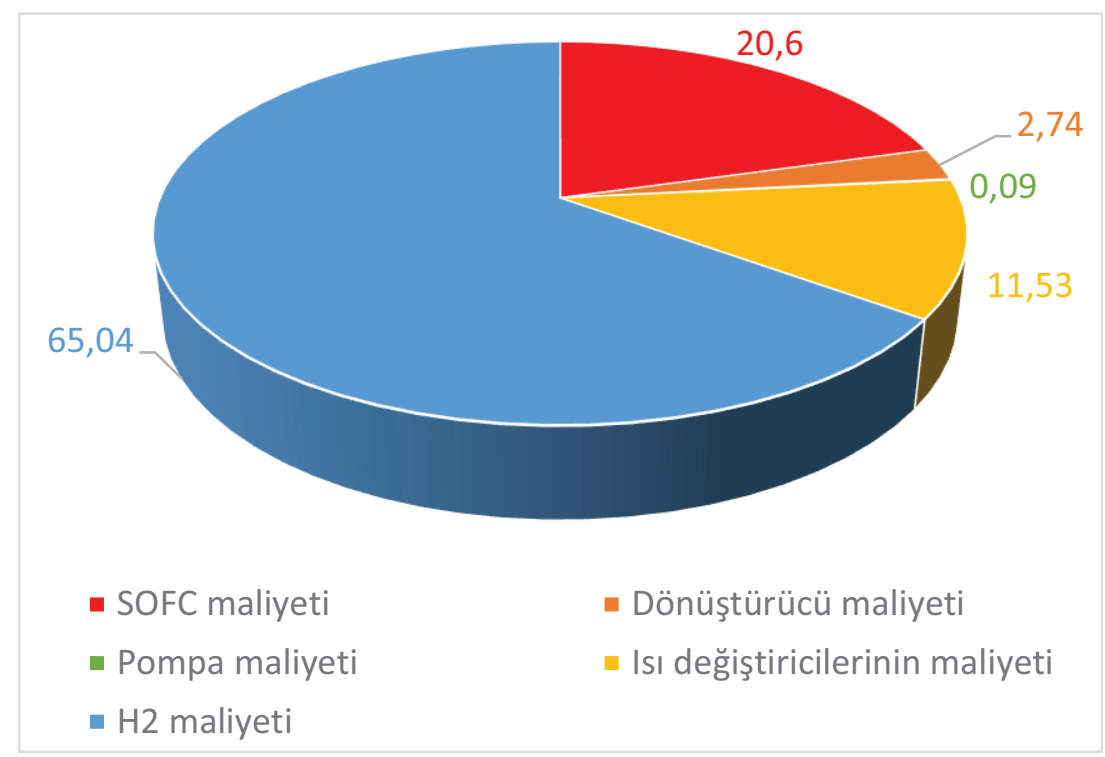

Şekil 6. $1173 \mathrm{~K}$ çalışma sıcaklığı ve $3 \mathrm{kA} / \mathrm{m}^{2}$ akım yoğunluğundaki SOFC güç sisteminin yüzdelik olarak maliyet bileşenleri

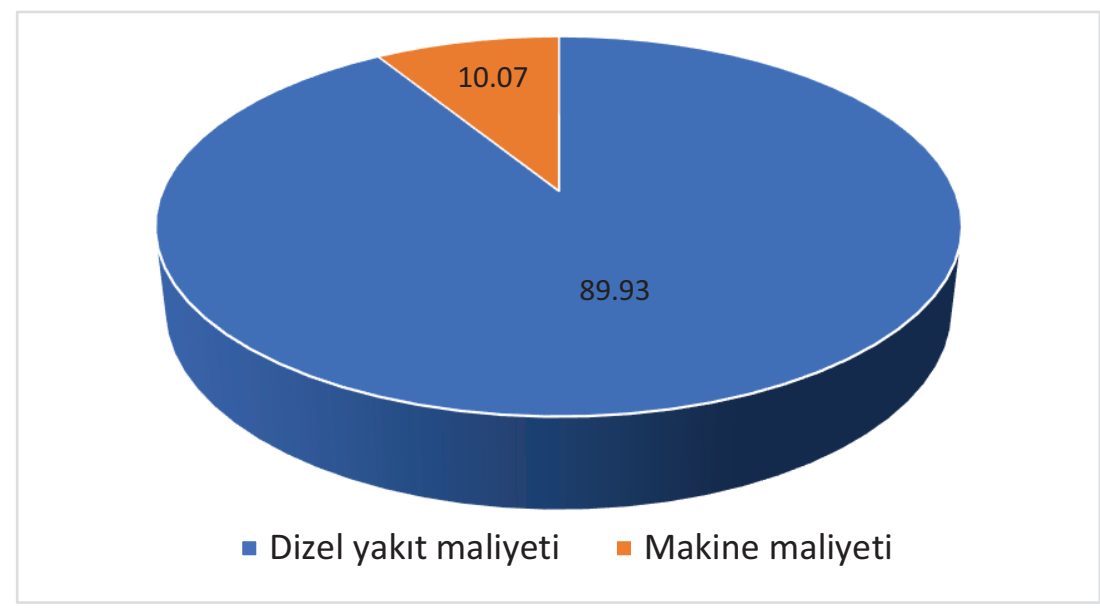

Şekil 7. Referans güç sisteminin yüzdelik olarak maliyet bileşenleri 
Sistemin $1173 \mathrm{~K}$ sıcaklık ve $3 \mathrm{kA} / \mathrm{m}^{2}$ akım yoğunluğundaki çalışma koşullarının temel kayıp mekanizmaları ile net potansiyelinin akım yoğunluğuna bağlı değişimi ise Şekil 8'de gösterilmiştir. Şekil 8'e göre direnç ve etkinleşme kayıpların etkisi oldukça küçük olup sistemin net potansiyelini konsantrasyon kayıpları belirlemektedir. Özellikle yüksek akım değerlerinde konsantrasyon kayıpları pil potansiyeli üzerinde daha baskın olmaktadır.

\section{Sonuçlar}

$\mathrm{Bu}$ çalışmada bir koster için SOFC güç sisteminin elektrokimyasal ve termodinamik olarak modellenmesi ve Aspen HYSYS yazılımında simülasyonu gerçekleştirilmiştir. Alternatif $\mathrm{CO}_{2}$ emisyon azaltma yöntemleri ile fizibilite ve maliyet açısından daha etkin bir karşılaştırma yapabilmek için birim $\mathrm{CO}_{2}$ azaltma maliyeti üzerinden sistemin ekonomik analizi gerçekleştirilmiştir. Ekonomik analiz, çalışmada kullanılan geminin referans güç sisteminin bu çalışmada önerilen güç sistemiyle değiştirilmesinden kaynaklanan maliyet artışı ve azaltılan $\mathrm{CO}_{2}$ emisyon miktarı değerlerinden yola çıkılarak gerçekleştirilmiştir. Kurulan model üzerinden yakıt pilinin farklı çalışma sıcaklıkları ve akım yoğunluklarının ekonomik analiz üzerine etkileri incelenmiştir.

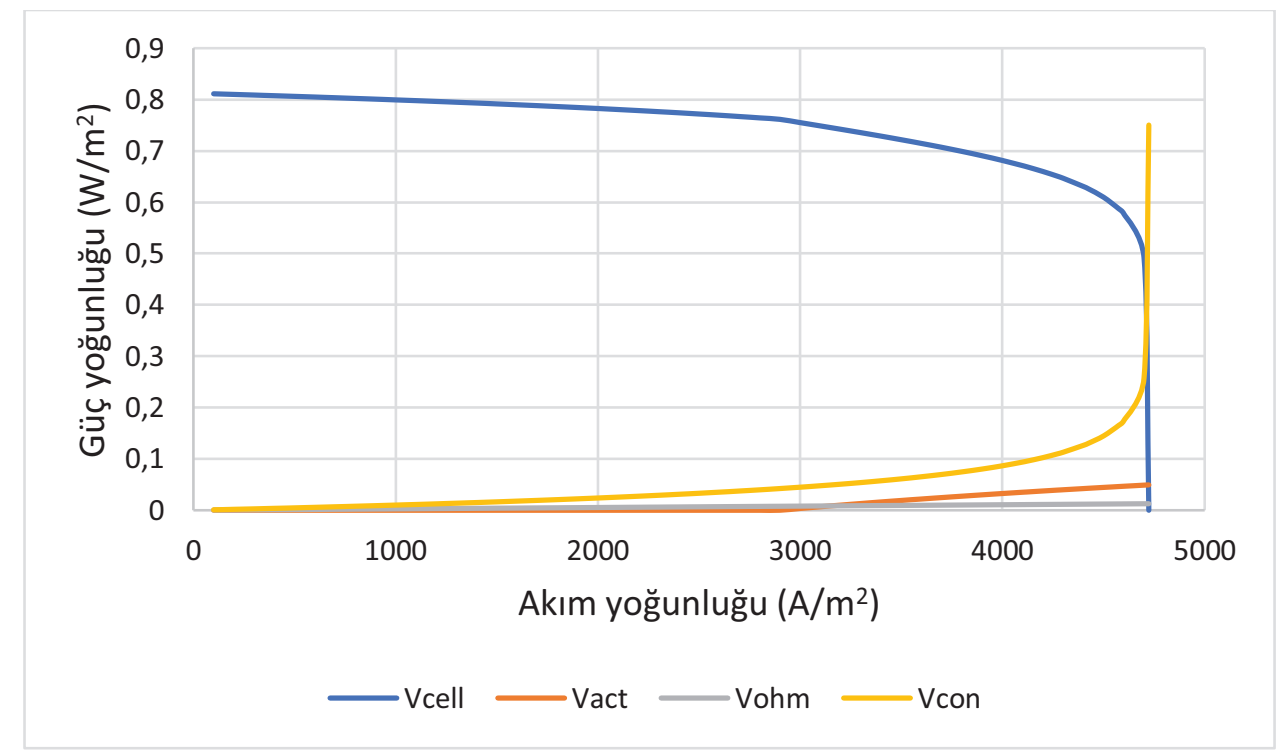

Şekil 8. Sistemin temel kayıp mekanizmaları ile net potansiyelinin akım yoğunluğuna bağlı değişimi

SOFC'nin çalışma akım yoğunluğunun artırılması güç yoğunluğunu artırıp, ihtiyaç duyulan pil yüzey alanını ve SOFC ilk yatııım maliyetini azaltır, ancak pil verimini düşürür. SOFC'nin çalışma sıcaklığııın artırılması ise yine ihtiyaç duyulan pil yüzey alanını ve SOFC ilk yatırım maliyetini azaltırken, daha değerli malzeme kullanımını gerektirir, kayıp mekanizmalarına göre pil verimini etkiler. Sonuç olarak incelenen koşullarda akım yoğunluğunun seçimi birim $\mathrm{CO}_{2}$ azaltma maliyetini \%10.0'a, sıcaklığın seçimi ise birim $\mathrm{CO}_{2}$ azaltma maliyetini \%26.08'e kadar azaltmıştır.

Uygun çalışma koşullarında SOFC güç sistemi için $\mathrm{CO}_{2}$ azaltma maliyeti 302.2 USD/ton $\mathrm{CO}_{2}$ olarak hesaplanmış olup literatürdeki $\mathrm{H}_{2}$ ve $\mathrm{NH}_{3}$ yakıtlı, gemilerde kullanılan yakıt pillerine göre çok daha uygun maliyetlidir. Ayrıca yine literatürdeki elektrik, hibrit veya tek başına $\mathrm{H}_{2}$ yakıtlı içten yanmalı makine, hibrit veya tek başına $\mathrm{NH}_{3}$ yakıtlı içten yanmalı makine gibi sıfır emisyonlu diğer $\mathrm{CO}_{2}$ azaltma teknoloji ve yöntemlerine göre daha uygun maliyetli olup, biyoyakıt kullanımı yöntemi ile rekabet edebilecek düzeydedir. Ancak benzer koşullardaki CCS ile hız düşürme yöntemlerine göre maliyeti çok daha yüksek olup sistemin ve SOFC maliyetlerinin düşürülmesi gerekmektedir. 
Sistemin toplam maliyeti üzerindeki en büyük ve dominant etkiyi $\mathrm{H}_{2}$ yakıt maliyeti oluşturmaktadır. Temiz enerjilere duyulan intiyaç doğrultusunda $\mathrm{H}_{2}$ 'nin gelecekte yığın üretim ve tedariğinin maliyetleri ciddi ölçüde azaltacağı düşünülmektedir. Sistemin maliyeti üzerindeki en büyük ikinci etki ise SOFC ilk yatırım maliyeti olup özellikle kimyasal bozulmadan kaynaklanan kayıplar bu maliyet üzerinde etkilidir. SOFC'nin kimyasal bozulmadan kaynaklı kaybının 1.000 saatte 6 mV'dan 1 mV'a düşürülmesi SOFC güç sisteminin birim $\mathrm{CO}_{2}$ azaltma maliyetini, incelenen koşullarda \%14.08 azaltmaktadır.

SOFC güç sisteminin toplam termal verimi seçilen çalışma ve kimyasal bozulmanın olmadığı koşullarda \%51.05 olup kimyasal bozulma etkisiyle verim \%29.38 azalmıştır. Kimyasal bozulmaya rağmen sistemin yakıt pili ömrü sonunda toplam ortalama termal verimi \%43.58'e düşmesine rağmen referans güç sisteminin veriminden yine de yüksektir.

\section{Referanslar}

Ahn, J., Park, S.H., Noh, Y., Choi, B. II, Ryu, J., Chang, D. ve Brendstrup, K.L.M. (2018). Performance and availability of a marine generator-solid oxide fuel cell-gas turbine hybrid system in a very large ethane carrier. Journal of Power Sources, 399, 199-206.

Aijjou, A., Raihani, A., Mohammedia, E. De ve Grid, S. (2019). Study on container ship energy consumption. Paper presented at the 8th Energy and Sustainability conference, Coimbra, Portugal, July $3-5,2019$

Anyenya, G.A. (2017). Solid-Oxide Fuel Cells for Unconventional Oil and Gas Production, Colorado School of Mines, Mechanical Engineering, Doctor of Philosophy.

Armi, C.D., Micheli, D. ve Taccani, R. (2021). Comparison of different plant layouts and fuel storage solutions for fuel cells utilization on a small ferry. International Journal of Hydrogen Energy, 46(26), 13878-13897.

Aspentech Inc, (2015). Aspen HYSYS V8.8.

Baldi, F., Moret, S., Tammi, K. ve Maréchal, F. (2020). The role of solid oxide fuel cells in future ship energy systems. Energy, 194.

Bassam, A.M., Phillips, A.B., Turnock, S.R. ve Wilson, P.A. (2017). Development of a multi-scheme energy management strategy for a hybrid fuel cell driven passenger ship. International Journal of Hydrogen Energy, 42(1), 623-635.

Birol, F. (2019). The Future of Hydrogen: Seizing Today's Opportunities, IEA Report prepared for the G20.

Buhaug, $\varnothing$., Corbett, J.J., Endresen, O., Eyring, V., Faber, J., Hanayama, S., Lee, D.S., Lindstad, H., Markowska, A.Z., Mjelde, A., Nelissen, D., Nilsen, J., Pålsson, C., Winebrake, J.J., Wu, W. ve Yoshida, K. (2009). Second IMO GHG Study 2009.

Buli, N. ve Abnett, K. (2021). Europe's carbon price tops 40 euros for first time,. Reuters. https://www.reuters.com/article/us-eu-carbontrading-idUSKBN2AB2BT [Online] [Erişim 26.04.2021] Bureau Veritas, 2021. BV Fleet. https://marine-offshore.bureauveritas.com/bv-fleet/\#/bv-fleet/shipadv [Online] [Erişim 26.04.2021]

Bureau Veritas, (2020). Rules for the Classification of Steel Ships, Part C-Machinery, Electricity, Automation and Fire Protection, Paris. 
Choi, C.H., Yu, S., Han, I.S., Kho, B.K., Kang, D.G., Lee, H.Y., Seo, M.S., Kong, J.W., Kim, G., Ahn, J.W., Park, S.K., Jang, D.W., Lee, J.H. ve Kim, M. (2016). Development and demonstration of PEM fuel-cellbattery hybrid system for propulsion of tourist boat. International Journal of Hydrogen Energy, 41(5), 3591-3599.

Costa, A.N., Neves, M.V.S., Cruz, M.E. ve Vieira, L.S. (2011). Maximum profit cogeneration plant MPCP: System modeling, optimization problem formulation, and solution. Journal of Brazilian Society Mechanical Sciences and Engineering, 33(1), 58-66.

Dall'Armi, C., Micheli, D. ve Taccani, R. (2021). Comparison of different plant layouts and fuel storage solutions for fuel cells utilization on a small ferry. International Journal of Hydrogen Energy, 46(26), 13878-13897.

De-Troya, J.J., Álvarez, C., Fernández-Garrido, C. ve Carral, L. (2016). Analysing the possibilities of using fuel cells in ships. International Journal of Hydrogen Energy, 41(4), 2853-2866.

Dogdibegovic, E., Wang, R., Lau, G. Y., ve Tucker, M. C. (2019). High performance metal-supported solid oxide fuel cells with infiltrated electrodes. Journal of Power Sources, 410, 91-98.

Evrin, R.A. ve Dincer, I. (2019). Thermodynamic analysis and assessment of an integrated hydrogen fuel cell system for ships. International Journal of Hydrogen Energy, 44(13), 6919-6928.

Feenstra, M., Monteiro, J., van den Akker, J.T., Abu-Zahra, M.R.M., Gilling, E. ve Goetheer, E. (2019). Ship-based carbon capture onboard of diesel or LNG-fuelled ships. International Journal of Greenhouse Gas Control, 85, 1-10.

Fioriti, D., Giglioli, R., Poli, D., Lutzemberger, G., Vanni, A. ve Salza, P. (2017). Optimal sizing of a minigrid in developing countries, taking into account the operation of an electrochemical storage and a fuel tank, Paper presented at the 6th International Conference on Clean Electrical Power: Renewable Energy Resources Impact, June, 2017.

Ganjehkaviri, A. ve Jaafar, M.N.M. (2014). Energy analysis and multi-objective optimization of an internal combustion engine-based CHP system for heat recovery. Entropy, 16(11), 5633-5653.

Giap, V.T., Lee, Y.D., Kim, Y.S., Ahn, K.Y., Kim, D.H. ve Lee, J. II (2020). System simulation and exergetic evaluation of hybrid propulsion system for crude oil tanker: A hybrid of solid-oxide fuel cell and gas engine. Energy Conversion and Management, 223, 113265.

Gielen, D. ve Taibi, E. (2019). Hydrogen's future: reducing costs, finding markets. https://energypost.eu/hydrogens-future-reducing-costs-finding-markets/[Online][Erişim 26.04.2021].

Giers, M., Jaworska, L. ve Antas, L. (2020). Global Hydrogen Market Who Will Dominate the Game? Warsaw.

Güler, E. ve Ergin, S. (2021). An Investigation on the Solvent Based Carbon Capture and Storage System by Process Modeling and Comparisons with Another Carbon Control Methods for Different Ships. International Journal of Greenhouse Gas Control, 110, September 2021, 103438.

Hackl, R. ve Harvey, S., (2013). Identification, cost estimation and economic performance of common heat recovery systems for the chemical cluster in Stenungsund, Chalmers University of Technology, Department of Energy and Environment, Project Report. 
International Maritime Organization, (2018). Adoption of the initial IMO strategy on reduction of GHG emissions from ships and existing IMO activity related to reducing GHG emissons in the shipping sector.

Lloyd's Register ve UMAS, (2018). Zero-Emission Vessels 2030. How do we get there. Lloyd's Register Group Limited and UMAS.

Luo, X. ve Wang, M. (2017). Study of solvent-based carbon capture for cargo ships through process modelling and simulation. Applied Energy, 195, 402-413.

Man Energy Solutions, (2018). https://marine.man-es.com/two-stroke/ceas [Online] [Erişim 26.04.2021].

Marine Environment Protection Committee, (2020). Report of the Marine Environment Protection Committee on its Seventy Fifth Session.

Marine Insight, (2020). EU Parliament Votes To Make Shipping Pay For CO2 Emissions. https://www.marineinsight.com/shipping-news/eu-parliament-votes-to-make-shipping-pay-for-co2emissions/\#: :text=Shipping is the only sector,€24 billion a year. [Online] [Erişim 26.04.2021].

MTU-solutions, 2019. Marine Diesel Engine S60 for vessels with unrestricted continuous operation. https://www.mtu-solutions.com/content/dam/mtu/products/defense/marine-and-offshore-serviceand-supply/main-propulsion/mtu-series 60/3231191_Marine_spec_S60_1A.pdf. [Online] [Erişim 26.04.2021]

Nordin, A. ve Majid, M.A.A., (2016). Parametric study on the effects of pinch and approach points on heat recovery steam generator performance at a district cooling system. Journal of Mechanical Engineering and Sciences, 10 (2), 2134-2144.

Ouyang, T., Zhao, Z., Lu, J., Su, Z., Li, J. ve Huang, H. (2020). Waste heat cascade utilisation of solid oxide fuel cell for marine applications. Journal of Cleaner Production, 275, 124133.

Park, S., Vohs, J.M. ve Gorte, R.J. (2000). Direct oxidation of hydrocarbons in a solid-oxide fuel cell. Nature, 404 (6775), 265-267.

Park, S.H., Lee, Y.D. ve Ahn, K.Y. (2014). Performance analysis of an SOFC/HCCl engine hybrid system: System simulation and thermo-economic comparison. International Journal of Hydrogen Energy, 39 (4), 1799-1810.

Parks, G., Boyd, R., Cornish, J. ve Remick, R. (2014). Hydrogen Station Compression, Storage, and Dispensing Technical Status and Costs: Systems Integration, International Renewable Energy Laboratory, Technical Report.

Peng, D. ve Robinson, D.B. (1976). A New Two-Constant Equation of State. Industrial \& Engineering Chemistry Fundamentals, 15(1), 59-64.

Sapra, H., Stam, J., Reurings, J., van Biert, L., van Sluijs, W., de Vos, P., Visser, K., Vellayani, A.P. ve Hopman, H. (2021). Integration of solid oxide fuel cell and internal combustion engine for maritime applications. Applied Energy, 281, 115854.

Sohal, M.S. (2009). Degradation in solid oxide cells during high temperature electrolysis, Idaho National Laboratory, Technical Report. 
Shirmohammadi, R., Aslani, A., Ghasempour, R., Romeo, L. M., ve Petrakopoulou, F. (2021). Process design and thermoeconomic evaluation of a $\mathrm{CO} 2$ liquefaction process driven by waste exhaust heat recovery for an industrial $\mathrm{CO} 2$ capture and utilization plant. Journal of Thermal Analysis and Calorimetry, 145(3), 1585-1597.

Ship\&Bunker, (2021). Rotterdam Bunker Prices. https://shipandbunker.com/prices/emea/nwe/nlrtm-rotterdam\#ULSFO. [Online] [Erişim 02.06.2021]

Van Biert, L., Godjevac, M., Visser, K. ve Aravind, P. V. (2016). A review of fuel cell systems for maritime applications. Journal of Power Sources, 327, 345-364.

Woodyard, D., (2009). Pounder's marine diesel engines and gas turbines. Butterworth-Heinemann.

Wu, P. ve Bucknall, R. (2020). Hybrid fuel cell and battery propulsion system modelling and multiobjective optimisation for a coastal ferry. International Journal of Hydrogen Energy, 45(4), 3193-3208.

Yan, Z., He, A., Hara, S. ve Shikazono, N. (2019). Modeling of solid oxide fuel cell (SOFC) electrodes from fabrication to operation: Microstructure optimization via artificial neural networks and multi-objective genetic algorithms. Energy Conversion Management, 198, 111916.

Yonekura, T., Yachikawa, Y., Yoshizuma, T., Shiratori, Y., Ito, K. ve Sasaki, K. (2011). Exchange Current Density of Solid Oxide Fuel Cell Electrodes. ECS Transactions, 35(1), 1007-1014.

Zhang, X., Chan, S.H., Li, G., Ho, H.K., Li, J. ve Feng, Z. (2010). A review of integration strategies for solid oxide fuel cells. Journal of Power Sources, 195(3), 685-702. 